Provided for non-commercial research and education use. Not for reproduction, distribution or commercial use.

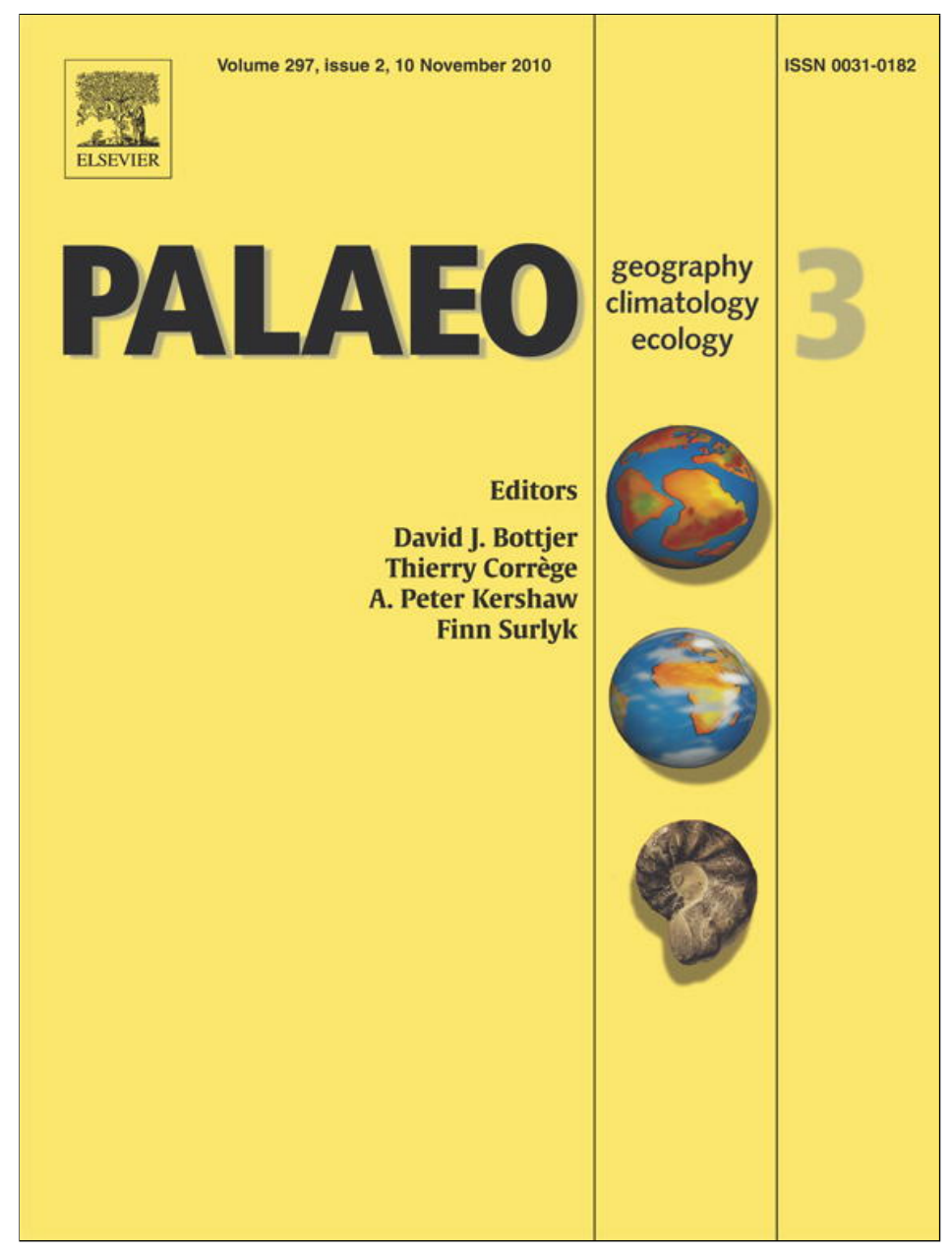

This article appeared in a journal published by Elsevier. The attached copy is furnished to the author for internal non-commercial research and education use, including for instruction at the authors institution and sharing with colleagues.

Other uses, including reproduction and distribution, or selling or licensing copies, or posting to personal, institutional or third party websites are prohibited.

In most cases authors are permitted to post their version of the article (e.g. in Word or Tex form) to their personal website or institutional repository. Authors requiring further information regarding Elsevier's archiving and manuscript policies are encouraged to visit:

http://www.elsevier.com/copyright 


\title{
Toarcian carbon isotope shifts and nutrient changes from the Northern margin of Gondwana (High Atlas, Morocco, Jurassic): Palaeoenvironmental implications
}

\author{
S. Bodin ${ }^{\text {a,* }}$, E. Mattioli ${ }^{\text {b }}$, S. Fröhlich ${ }^{\text {a }}$, J.D. Marshall ${ }^{\text {c }}$, L. Boutib ${ }^{\text {d }}$, S. Lahsini ${ }^{\text {d }}$, J. Redfern ${ }^{\text {a }}$ \\ ${ }^{a}$ North Africa Research Group, Basin Studies and Petroleum Geosciences, School of Earth, Atmospheric and Environmental Sciences, University of Manchester, Williamson Building, \\ oxford Road, Manchester M13 9PL, United Kingdom \\ b UMR 5125 PEPS, Université Lyon 1, Campus de la Doua, Bâtiment Géode, 69622 Villeurbanne Cedex, France \\ c Department of Earth and Ocean Sciences, University of Liverpool, Liverpool L69 3GP, United Kingdom \\ d Office National des Hydrocarbures et des Mines (ONHYM), 34 Avenue Al Fadila, 10050 Rabat, Morocco
}

\section{A R T I C L E I N F O}

\section{Article history:}

Received 1 October 2009

Received in revised form 23 July 2010

Accepted 27 August 2010

Available online 21 September 2010

\section{Keywords:}

Early Jurassic

Oceanic Anoxic Event

Pliensbachian-Toarcian boundary

Southern Tethys

Phosphorus

Carbonate platform drowning

\begin{abstract}
A B S T R A C T
The Early Toarcian is marked by a global perturbation of the carbon cycle and major marine biological changes. These coincide with a general decrease in calcium carbonate production and an increase in organic carbon burial, and culminate in the so-called Toarcian Oceanic Anoxic Event. It is believed that the environmental crisis was triggered by the activity of the Karoo-Ferrar large igneous province. In order to further document the Early Toarcian palaeoenvironmental perturbations, carbon isotope, total organic matter, calcareous nannofossils and phosphorus content of the Amellago section in the High Atlas rift basin of Morocco were investigated. This section is extremely expanded compared to the well-studied European sections. Its position along the northern margin of the Gondwana continent is of critical importance because it enables an assessment of changes of river nutrient input into the western Tethyan realm. The carbon isotope curve shows two negative excursions of equal thickness and amplitude, at the PliensbachianToarcian boundary and at the transition from the Polymorphum to the Levisoni Zone. This confirms the supra-regional nature of these shifts and highlights the possible condensation of the first "boundary" shift in European sections. Phosphorus content is used to trace palaeo-nutrient changes and shows that the two negative carbon isotope shifts are associated with increased nutrient levels, confirming that these episodes are related to enhanced continental weathering, probably due to elevated greenhouse gases in the atmosphere. In the High Atlas Basin, the increase in nutrient levels at the Pliensbachian-Toarcian boundary is moreover likely to be the main factor responsible for the coeval demise of the Saharan carbonate platform. A middle Toarcian event, centered on the boundary between the Bifrons and Gradata Zones, characterized by a positive carbon isotope excursion and nutrient level rise, is documented in the Amellago section.
\end{abstract}

(c) 2010 Elsevier B.V. All rights reserved.

\section{Introduction}

The Early Toarcian is characterized by major marine biological changes (Little and Benton, 1995; Harries and Little, 1999; Cecca and Macchioni, 2004; Mattioli and Pittet, 2004; Wignall et al., 2005; Wignall and Bond, 2008; Dera et al., 2010) and a decrease in carbonate accumulation (Dromart et al., 1996; Blomeier and Reijmer, 1999; Erba, 2004; Mattioli et al., 2004; Tremolada et al., 2005). It is also noticeable for its widespread organic matter deposition occurring during the so-called Toarcian Oceanic Anoxic Event (T-OAE; Jenkyns, 1985, 1988; Baudin et al., 1989; but see also McArthur et al., 2008a) and the associated perturbation of the carbon cycle. This latter is marked by a pronounced negative carbon isotope shift recorded in

\footnotetext{
* Corresponding author. Present address: Institute for Geology, Mineralogy and Geophysics, Ruhr-University Bochum, Universitätsstrasse 150, D-44801 Bochum, Germany.

E-mail address: stephane.bodin@rub.de (S. Bodin).
}

marine carbonates and organic matter, brachiopods, biomarkers and fossil wood around the boundary of the Polymorphum and Levisoni Zones (Jenkyns and Clayton, 1997; Hesselbo et al., 2000; Schouten et al., 2000; Röhl et al., 2001; Schmid-Röhl et al., 2002; Van Breugel et al., 2006; Hesselbo et al., 2007; Suan et al., 2008a). It is however not observed in belemnite guards from England, Germany and Spain (Van de Schootbrugge et al., 2005; Gomez et al., 2008). The T-OAE is also marked by an increase in the ${ }^{87} \mathrm{Sr} /{ }^{86} \mathrm{Sr}$ ratio (McArthur et al., 2000) and a positive excursion of Os isotopes which are interpreted to document a substantial increase in continental weathering (Cohen et al., 2004). Oxygen isotope and $\mathrm{Mg} / \mathrm{Ca}$ ratio recovered from belemnite guards indicate that the T-OAE is coeval with a $6-7{ }^{\circ} \mathrm{C}$ warming of seawater (McArthur et al., 2000; Bailey et al., 2003; Rosales et al., 2004; van de Schootbrugge et al., 2005; Gomez et al., 2008). This warming is also observed in southwestern Tethyan brachiopods (Suan et al., 2008a) and northwestern Tethyan fish teeth (Dera et al., 2009a). Finally, changes in phytoplankton assemblages point toward higher nutrient input and fertility prior to, or during the 
event (Erba, 2004; Mattioli and Pittet, 2004; Mattioli et al., 2004, 2008; Suan et al., 2008a).

The negative excursion associated with the T-OAE was originally explained by the upwelling of poorly oxygenated water enriched in isotopically light dissolved inorganic carbon (Küspert, 1982; see also Sælen et al., 1996). The accumulation of evidence that the negative isotopic excursion was global in nature and found to affect both the ocean and atmospheric reservoir, led Hesselbo et al. (2000) to propose a massive methane gas hydrate injection in the ocean-atmosphere system as the source of the isotopically light carbon (see also Kemp et al., 2005). Alternative models suggest that thermal metamorphism of carbon-rich sediments in the Karoo-Ferrar large igneous province provided the source of isotopically light carbon (McElwain et al., 2005; Svensen et al., 2007). Calculation of the timing of the excursion by spectral analysis (Suan et al., 2008b) supports this argument. Nevertheless, the global nature of the Early Toarcian negative carbon isotope excursion is challenged by isotopic records of belemnite rostra (van de Schootbrugge et al., 2005; Gomez et al., 2008), leading van de Schootbrugge et al. (2005) to favour the initial upwelling "Küspert" model. This model is however unable to explain the presence of the negative excursion in continental wood. The different models proposed so far have been discussed in details by Cohen et al. (2007, see also McArthur et al., 2008b). Apart from dismissing the belemnite record (e.g. Hesselbo et al., 2007; Suan et al., 2008b) or the continental record (van de Schootbrugge et al., 2005), no explanation is presently available to clarify this discrepancy.

Recently, Hesselbo et al. (2007) and Littler et al. (2010) have identified an earlier large-amplitude negative carbon isotope excursion in bulk carbonate, bulk organic matter and macroscopic fossil wood, near the Pliensbachian-Toarcian boundary in Portugal and England. This "boundary" excursion is also documented in brachiopod calcite in the Peniche section (Suan et al., 2008a) where the negative shift is less than $2 \mathrm{~m}$ thick but of the same amplitude as the T-OAE negative shift in the Peniche section (i.e. both show a $2 \%$ drop in carbon isotope values but the T-OAE negative shift is recorded within a $15 \mathrm{~m}$ interval in that section). Oxygen isotope records from brachiopods indicate that an almost identical warming to the one reported from the T-OAE moreover accompanies the "boundary" excursion (Suan et al., 2008a). This discovery leads to several questions about the significance of the events and their causes!

In order to further document the palaeoenvironmental changes occurring during the Early Toarcian, the Amellago section, situated in the High Atlas rift basin of Morocco (Fig. 1) was investigated. This

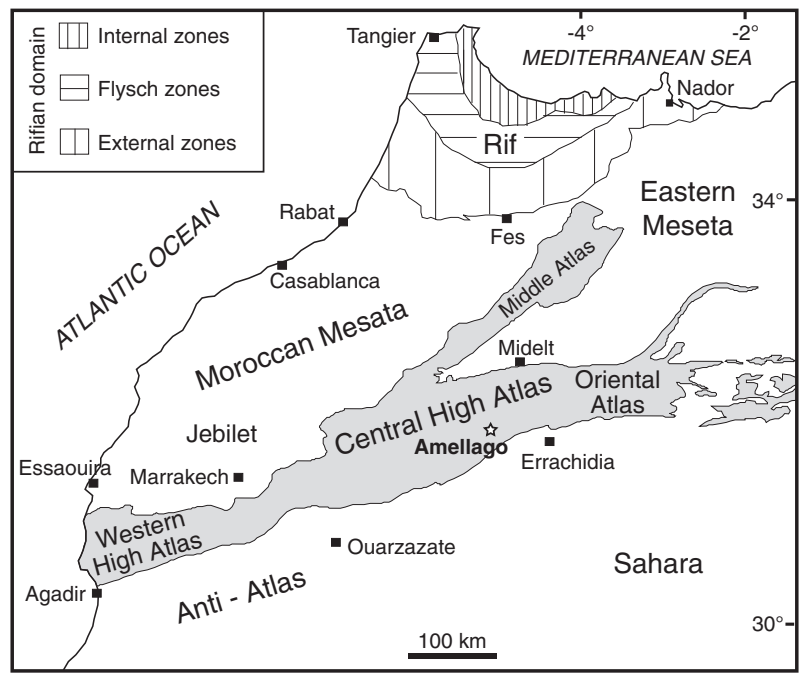

Fig. 1. Simplified structural map of Morocco and position of the Amellago section (modified after Lachkar et al., 2009). The Atlas range is shown in grey. study provides the first documentation of the Early Toarcian carbon isotope curve for the Northern Gondwana margin (most previous studies were located in the European domain). This is of critical importance for an assessment of the extent of the carbon cycle perturbation. The Early Jurassic sedimentation rate in this part of the High Atlas Basin was very high (the Toarcian being more than $600 \mathrm{~m}$ thick; Pierre, 2006; Bourillot et al., 2008), minimizing the likelihood of problems with condensation and stratigraphic gaps. Despite its position at the western end of the Tethys Ocean along the northern margin of the Gondwana continent, only a few studies have been undertaken to try to document the impact of palaeoenvironmental changes on Lower Toarcian sediments in the High Atlas. The previous investigations mainly focused on the platform drowning event that is observed in the High Atlas Basin at the Pliensbachian-Toarcian boundary (Blomeier and Reijmer, 1999; Lachkar et al., 2009). Dera et al. (2009b) documented clay mineral assemblage during the Pliensbachian-Toarcian in the western Tethyan realm, including the High Atlas of Morocco, to trace palaeoclimatic changes. However, the absence of kaolinite throughout the entire studied interval did not allow these authors to discuss such changes in the High Atlas.

This study presents a latest Pliensbachian-middle Toarcian dataset of stable carbon and oxygen isotopes, total organic and phosphorus content from the Amellago section. The carbon isotope record is used to document changes in the ocean-atmosphere carbon reservoir. Bulk-rock phosphorus content is used to assess nutrient changes in the ocean. The implications of our findings for the palaeoenvironmental changes during the Early Toarcian are discussed and a potential middle Toarcian event is introduced.

\section{Geological setting of the High Atlas}

The post-Hercynian geological history of Morocco was influenced by two significant events: (1) the opening of the northern Atlantic and western Tethys during the early Mesozoic and (2) the collision of Africa and Europe during the middle Cenozoic (Michard, 1976; Jacobshagen, 1988). These two events formed the Atlas System as well as the Rif Mountains. The Atlasic rift, which is associated with the first tectonic event, formed during two separated periods (Laville et al., 2004). Initial extension lasted from the Carnian to the earliest Jurassic, and this was followed by renewed subsidence from Toarcian times. Together, these lead to the formation of the fault-bounded Middle and High Atlas troughs, which are made up of several smaller depocenters, separated by synsedimentary highs (Studer and Du Dresnay, 1980).

The general palaeogeographic pattern of the central High Atlas region during the Early Jurassic was described as relatively deep marine in the centre and shallowing towards the northern and southern basin margins (Du Dresnay, 1971; Souhel et al., 2000; Fig. 2). However, a carbonate facies mosaic controlled by fault blocks developed during the Sinemurian and Pliensbachian, with a complex pattern of deep- and shallow-marine deposits throughout the central and eastern High Atlas. The Pliensbachian-Toarcian boundary is associated with an abrupt change from limestone-marl alternation to ubiquitous marl sedimentation in all the High Atlas depocentres (El Kamar et al., 1997-1998; Souhel et al., 1998; Fedan, 1999; Ettaki and Chellai, 2005). This feature was associated with sea-level rise interpreted as eustatic in origin by Warme (1988). It could however also be related to the drowning of the High Atlas carbonate platforms during the Early Toarcian (Blomeier and Reijmer, 1999; Wilmsen and Neuweiler, 2008; Lachkar et al., 2009), which would have lead to a halt in the shedding of carbonate platform ooze, which is responsible in some cases for limestone-marl alternation in epicontinental basins (Mattioli and Pittet, 2002; Reboulet et al., 2003). The thickness of the Toarcian marls and the intercalated shallow-marine deposits vary across the area. 


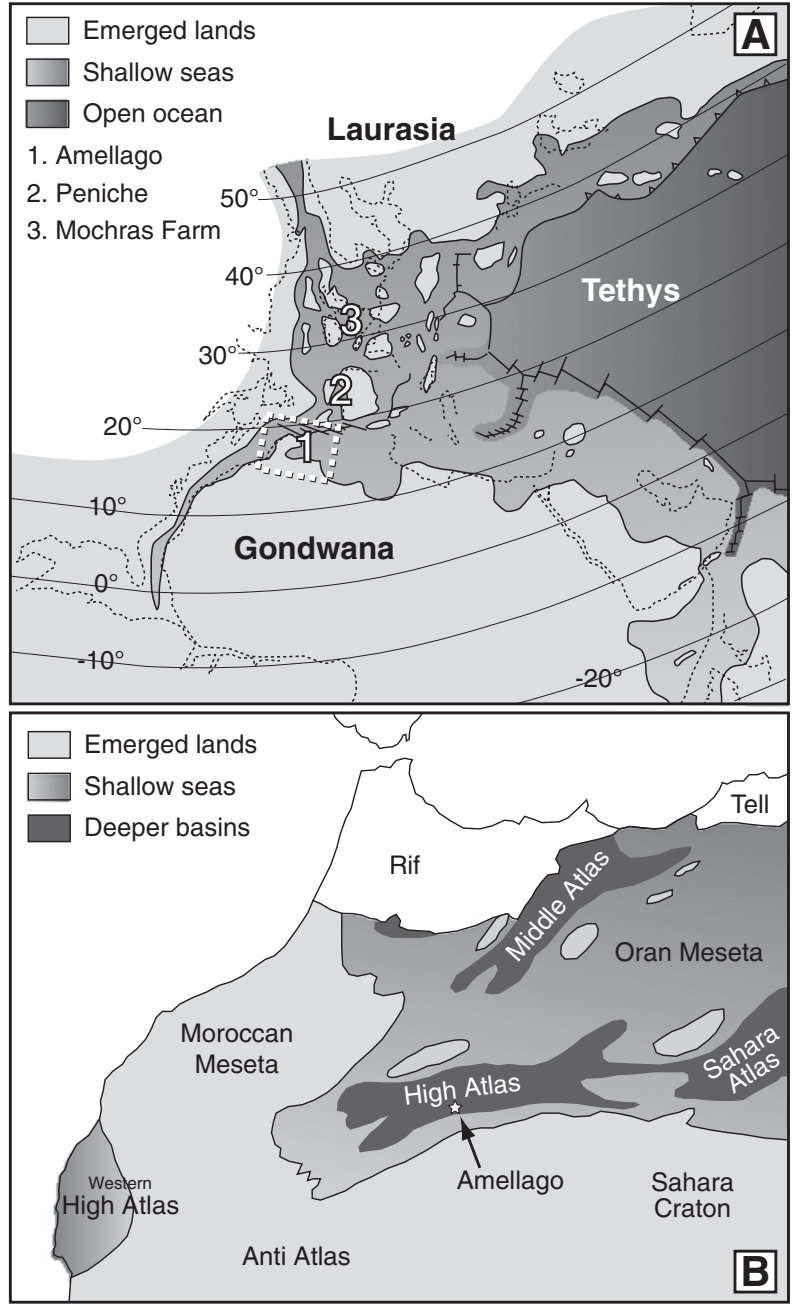

Fig. 2. Toarcian palaeogeographic map. A: Western Tethyan realm (Modified after Bassoulet et al., 1993) showing the location of the Amellago section along the northern Gondwana margin. The dashed rectangle highlights the limit of the second map. Numbers refer to sections discussed in the text. B: Palaeogeographic map of Morocco and western Algeria showing the major geological provinces and the location of the Amellago section near the southern edge of the Central High Atlas basin (modified from Blomeier and Reijmer, 1999; after Du Dresnay, 1971).

\section{Materials and methods}

The lithology of the Toarcian section was logged using a Jacob's staff to measure the true thickness of the outcropping strata. Rock samples for geochemical analysis were collected throughout the sections, and samples were taken as deep as possible from the outcrop, using a geological hammer to obtain less weathered specimens up to $10 \mathrm{~cm}$ below the surface. A total of 74 samples with an average weight of $250 \mathrm{~g}$ were collected.

A first set of 50 samples were selected to be analysed at Liverpool University for their carbon and oxygen stable isotope content of the bulk carbonate in the marls. After hand-crushing, they were analysed using a VG SIRA 12 isotope ratio mass spectrometer with an online common acid bath preparation device. Isotope ratios are reported with reference to the VPDB international scale. Long-term sample reproducibility is better than $0.1 \%$ for both carbon and oxygen isotope ratios. Carbon- and oxygen-isotope analysis of the remaining 24 samples was latterly performed at the facilities of the Institute for Geology, Mineralogy and Geophysics (Ruhr University Bochum, Germany) using a ThermoFinnigan MAT delta-S mass spectrometer (following the method of McCrea, 1950). Reproducibility $( \pm 1 \sigma)$, controlled by NBS19 and internal standards, was better than $\pm 0.06 \%$ 。 and $\pm 0.11 \%$ for, respectively, $\delta^{13} \mathrm{C}$ and $\delta^{18} \mathrm{O}$. Duplicate samples or parts of the section where the two data sets meet show that there is no significant discrepancy between the results from both laboratory.

Analyses of Phosphorus content were performed on all samples at the University of Neuchâtel. Around $100 \mathrm{mg}$ of powder were mixed with $1 \mathrm{ml}$ of $\mathrm{MgNO}_{3}$ and left to dry in an oven at $45^{\circ} \mathrm{C}$ for $2 \mathrm{~h}$. The samples were then ashed in a furnace at $550{ }^{\circ} \mathrm{C}$ for $2 \mathrm{~h}$. After cooling, $10 \mathrm{ml}$ of $1 \mathrm{~N} \mathrm{HCl}$ were added and the reaction tubes were shaken for $14 \mathrm{~h}$. The solutions were filtered with a $63 \mu \mathrm{m}$ filter, diluted by addition of $90 \mathrm{ml}$ of de-ionised water, and analysed using the ascorbic acid method of Eaton et al. (1995). For this process, the solution was mixed with ammonium molybdate and potassium antimonyl tartrate, which is an acid medium react with orthophosphate to form phosphomolybdic acid. This acid is reduced with ascorbic acid to form an intense blue colour. The intensity of the blue colour is determined with a photospectrometer (Perkin Elmer UV/Vis Photospectrometer Lambda 10). The concentration of $\mathrm{PO}_{4}$ in $\mathrm{mg} / \mathrm{L}$ is obtained by calibration with known standard solutions. Individual samples were measured three times and precision was better than $5 \%$. Replicate analyses of samples have a precision better than $8 \%$.

A total of 30 smear slides were prepared for nannofossil study by powdering a small amount of rock, dilution with water, spreading onto a cover glass and drying. Cover glasses were mounted on microscope slides using Rhodopas. Samples were prepared as homogeneously as possible, so that particle density in different slides is comparable. However, as discussed in Mattioli and Pittet (2004), this preparation technique does not guarantee a perfectly constant quantity of material on different smear slides. The density of material in each smear slide was thus estimated using the plates of Baccelle and Bosellini (1965) under an optical microscope as the mean density of particles in 10 fields of view at $500 \mathrm{X}$ magnification. Nannofossils were counted in a variable surface area of the smear slide under a light polarising microscope, at $1000 \mathrm{X}$ magnification. The surface analysed in each smear slide (varying from $6.4 \mathrm{~mm}^{2}$ in the richest samples to

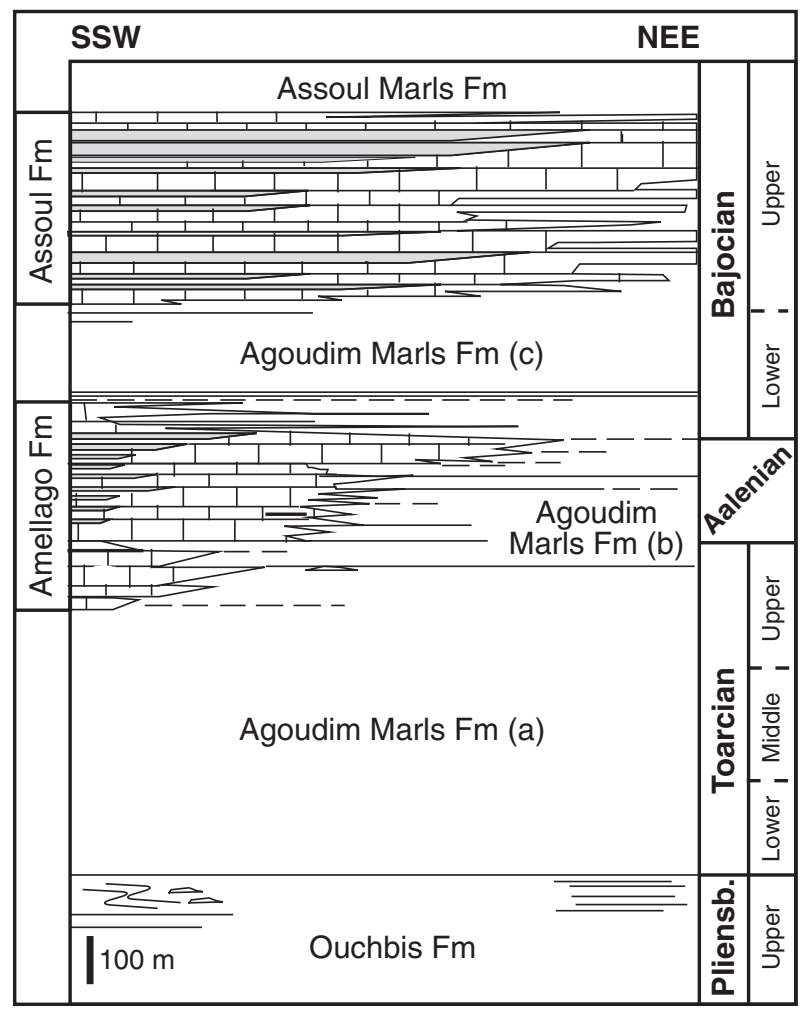

Fig. 3. Upper Pliensbachian-Bajocian stratigraphy for the Amellago area (after Bourillot et al., 2008; Pliensb. = Pliensbachian). 
$64 \mathrm{~mm}^{2}$ in the poorest ones) was used to calculate the total abundance of calcareous nannofossils. Total nannofossil abundance in one sample thus corresponds to the number of counted specimens divided by the surface of the slide that was analysed. This abundance per field of view was then standardised using the density of material on each smear slide. The abundance of nannofossils is expressed as number of specimens per $\mathrm{mm}^{2}$.

\section{Results}

\subsection{Lithology and stratigraphy}

The Amellago section is situated near the village of Amellago, in the foothills of the Jebel Bou Ifliyou, approximately $60 \mathrm{~km}$ southwest of Rich, in the central High Atlas (GPS coordinates: N31 $58^{\prime}$; W05 $01^{\prime}$; Figs. 1-2). The logged section is $540 \mathrm{~m}$ thick. It starts with $6 \mathrm{~m}$ of regular, several decimetre thick, limestone-marl alternations (Figs. 3-4). The limestone beds are mostly mudstone, but can sometimes consist of channelised crinoid-bearing wackestone-packstones. The limestone beds contain a rich ammonite fauna. According to the Tinejdad geological map (Hadri, 1997), these limestone-marl alternations correspond to the Ouchbis Formation, dated as Pliensbachian. The uppermost part of the Ouchbis Formation is dated as latest Pliensbachian (Elisa sub-Zone; Pierre, 2006). The limestone-marl alternations are overlain by a thick package of monotonous light to dark green marls belonging to the Agoudim Formation (Figs. 3-4). Thin (less than $10 \mathrm{~cm}$ thick) calcareous and siliciclastic beds are often intercalated in the first $70 \mathrm{~m}$ of the Agoudim Formation and the upper part of the section. These are interpreted as thin distal turbidites.
Pierre (2006) has reported ammonite finds in this section but he did not figure the Pliensbachian-Toarcian boundary (only the last $10 \mathrm{~m}$ of the Polymorphum Zone are figured in his section). These findings, however, allow the subdivision of the Amellago section into ammonite zones that combined with calcareous nannofossil data and the carbon isotope curve, permit correlation with well-documented European sections. The Pliensbachian-Toarcian boundary is marked by the boundary between the Ouchbis and Agoudim Formations. Above this, the Polymorphum-Levisoni boundary is taken near the base of the second negative carbon isotope shift, where the decrease in values becomes more pronounced. This accords with the sections in Portugal (Hesselbo et al., 2007) and Germany (Röhl et al., 2001; Schmid-Röhl et al., 2002). Thus, the thickness of the Polymorphum Zone is $73 \mathrm{~m}$. The following Levisoni Zone is $150 \mathrm{~m}$ thick. The middle Toarcian is ca. $200 \mathrm{~m}$ thick (Bifrons: $135 \mathrm{~m}$; Gradata: at least $50 \mathrm{~m}$, possibly $80 \mathrm{~m}$ ). No subdivision of the Upper Toarcian can be made in this section due to the lack of characteristic Upper Toarcian ammonites (Pierre, 2006).

\subsection{Calcareous nannofossils}

A total of 46 taxa were recorded in the Amellago section. Nannofossil preservation is generally moderate to poor with specimens often being fragmented (Fig. $5 \mathrm{a}-\mathrm{c}$ and $\mathrm{g}-\mathrm{i}$ ) or overgrown (Fig. $5 \mathrm{k}-1$ ). Because of the poor preservation, the abundance per gram of rock was not calculated, as it is not unlikely that diagenetic processes altered the apparent primary assemblage composition with a resultant loss in nannofossils. However, an estimation of abundance per square millimetre of the smear slide has been performed (Fig. 6).
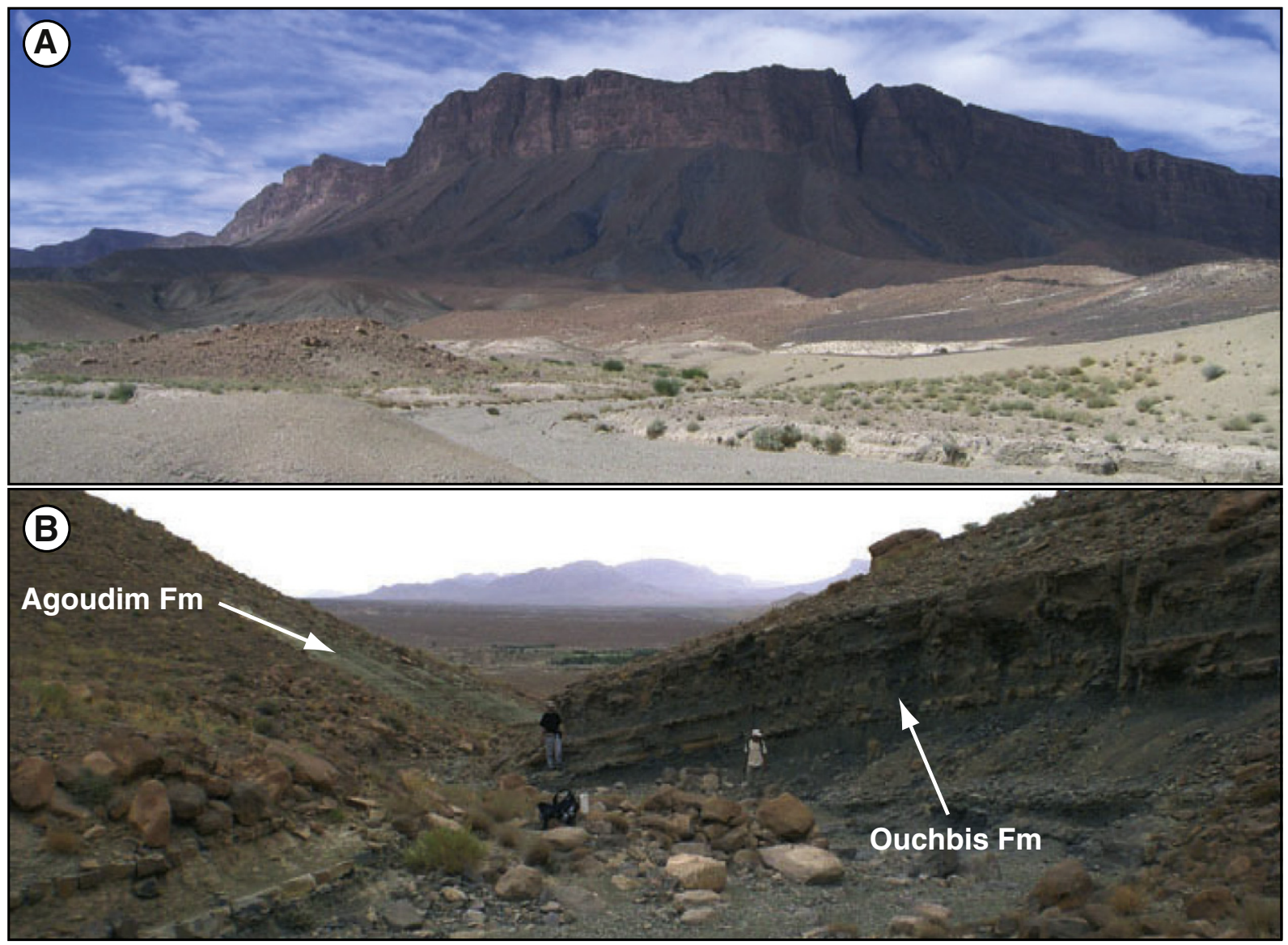

Fig. 4. A. Picture of the Jebel Bou Ifliyou (looking toward the NW) showing the foothill green marls of the Agoudim Formation capped by the oobioclastic carbonates of the Amellago Formation. The thickness of the Amellago Formation at this locality is ca. $300 \mathrm{~m}$ (Pierre, 2006). B. Boundary between the limestone-marls alternation of the Ouchbis Formation and the green marls of the Agoudim Formation. 


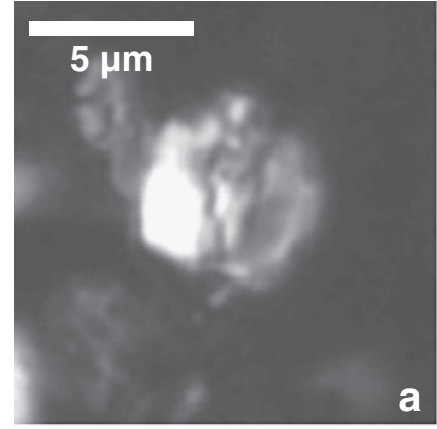

Mitrolithus jansae

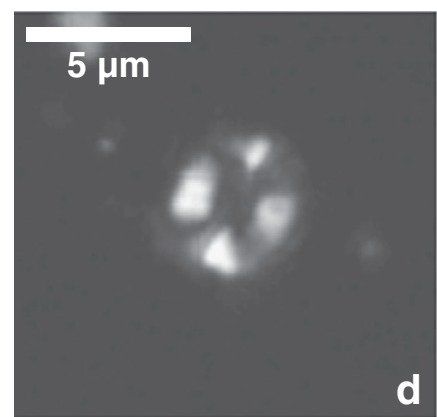

Similiscutum novum

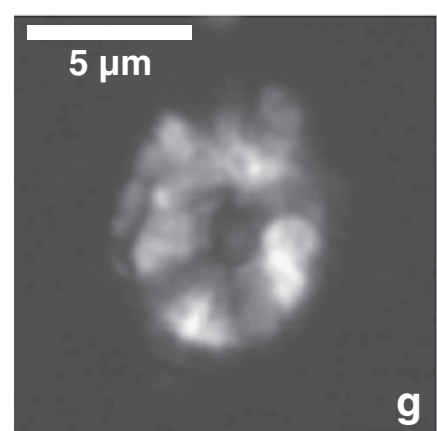

Similiscutum finchii

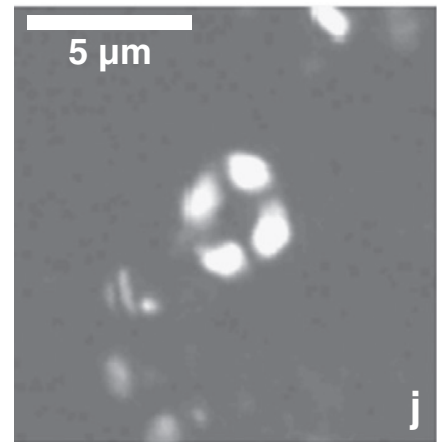

Lotharingius hauffii

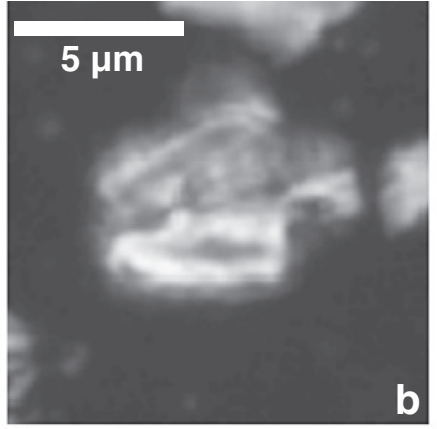

Mitrolithus jansae

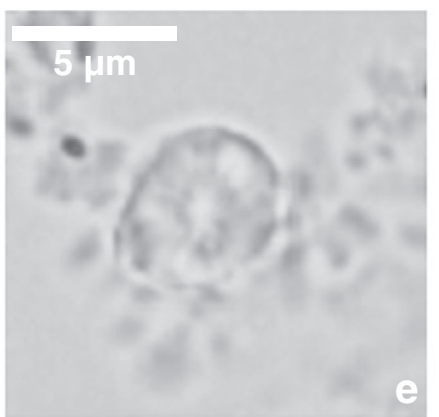

Similiscutum novum

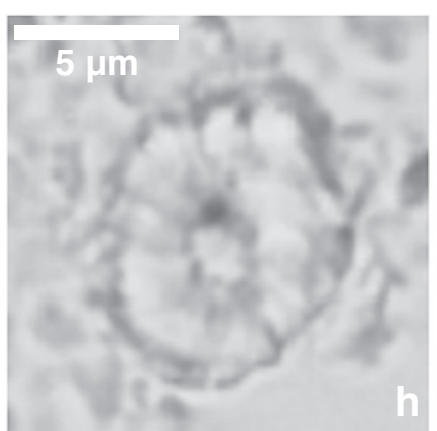

Similiscutum finchii

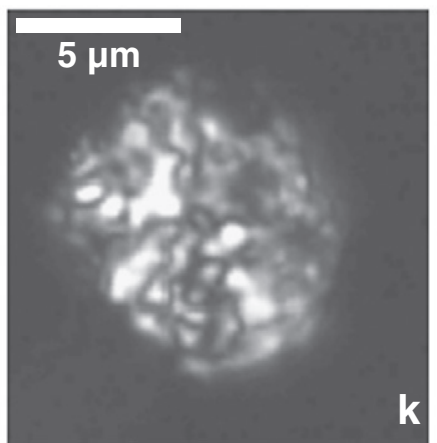

Schizosphaerella spp.

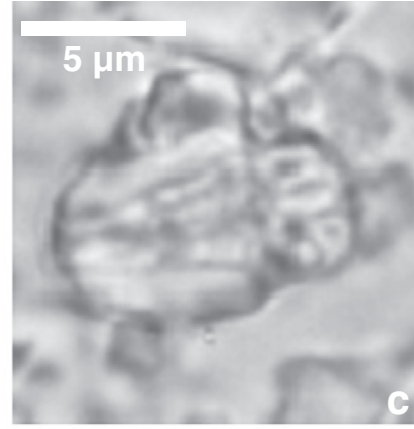

Mitrolithus jansae

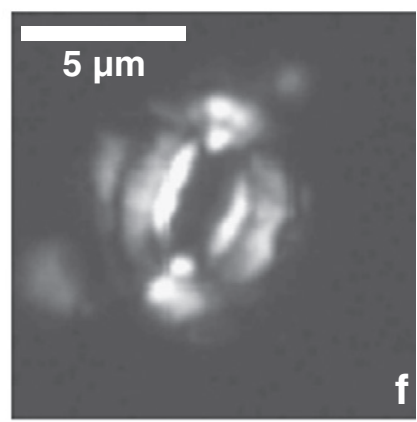

Biscutum grande

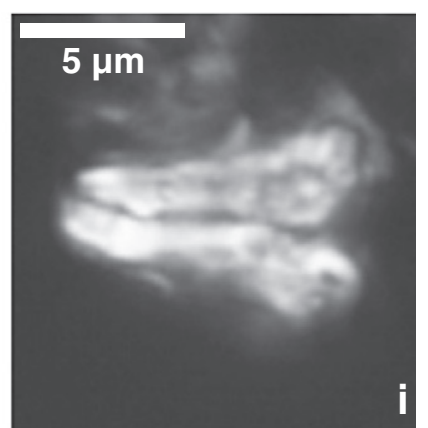

Carinolithus superbus

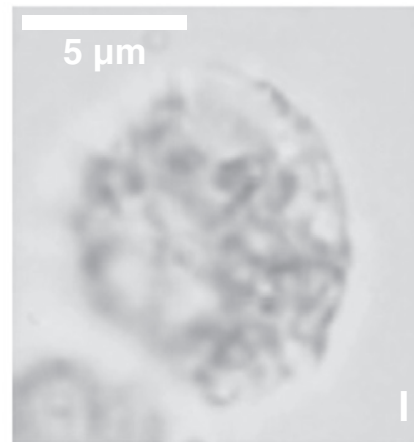

Schizosphaerella spp.

Fig. 5. Pictures of some nannofossil taxa recorded in the Amellago section. a. Sample 35; crossed polars. Specimen showing overgrowth. b. Sample 45; crossed polars. Specimen showing overgrowth. c. Same specimen as b; parallel polars. d. Sample 30; crossed polars. e. Same specimen as d; parallel polars. f. Sample 45; crossed polars. g. Sample 30; crossed polars. Specimen showing overgrowth. h. Same specimen as g; parallel polars. i. Sample 35; crossed polars. Specimen showing overgrowth. j. Sample 30; crossed polars. k. Sample 30; crossed polars. Fragmented specimen. l. Same specimen as k; parallel polars.

This shows that calcareous nannofossils are extremely rare in the Amellago section, with the exception of a few samples at the base of the studied section in the interval around the boundary negative excursion. In this interval, species richness is quite high but assemblages are largely dominated by the coccolith Mitrolithus jansae. The incertae sedis Schizosphaerella; Similiscutum novum and S. finchii are common between 30 and $47 \mathrm{~m}$ (Table 1 ).
In spite of the poor nannofossil preservation, some important biostratigraphical events (both first occurrence, FO, and a last occurrence, LO) have been recorded. The occurrence of Discorhabdus seems to be earlier in Amellago than in other southern Tethyan sections (Mattioli and Erba, 1999; Mattioli and Pittet, 2004). In fact, D. ignotus is recorded from the basal part of the section, around the PliensbachianToarcian boundary, and $D$. striatus first occurs $30 \mathrm{~m}$ above the base of the 


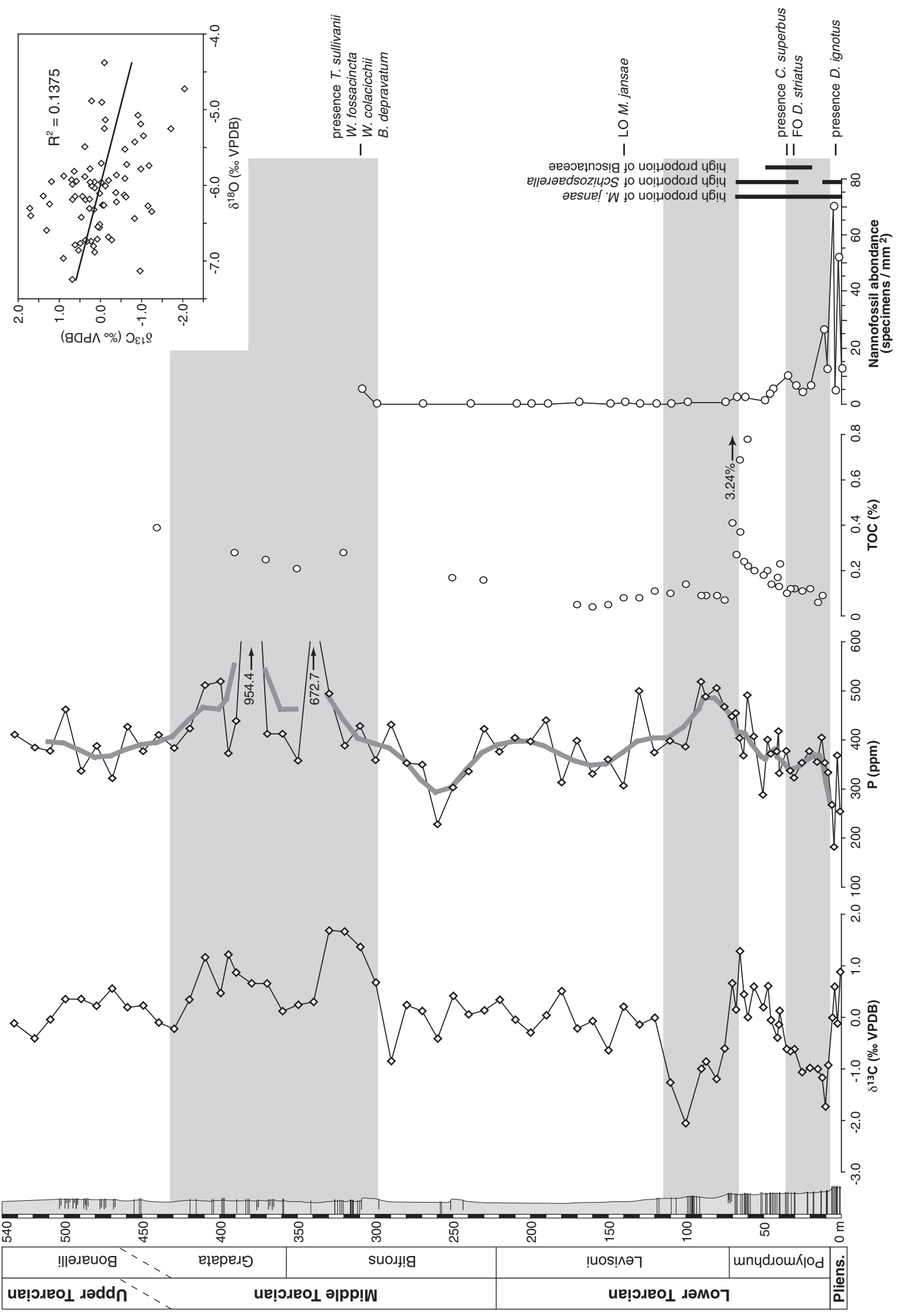


Table 1

Distribution chart of presence/absence of the 46 nannofossil taxa recorded in the Amellago section. Preservation state of samples is also reported: $P=$ poor preservation; $\mathrm{M}=$ moderate preservation. B indicates barren samples.

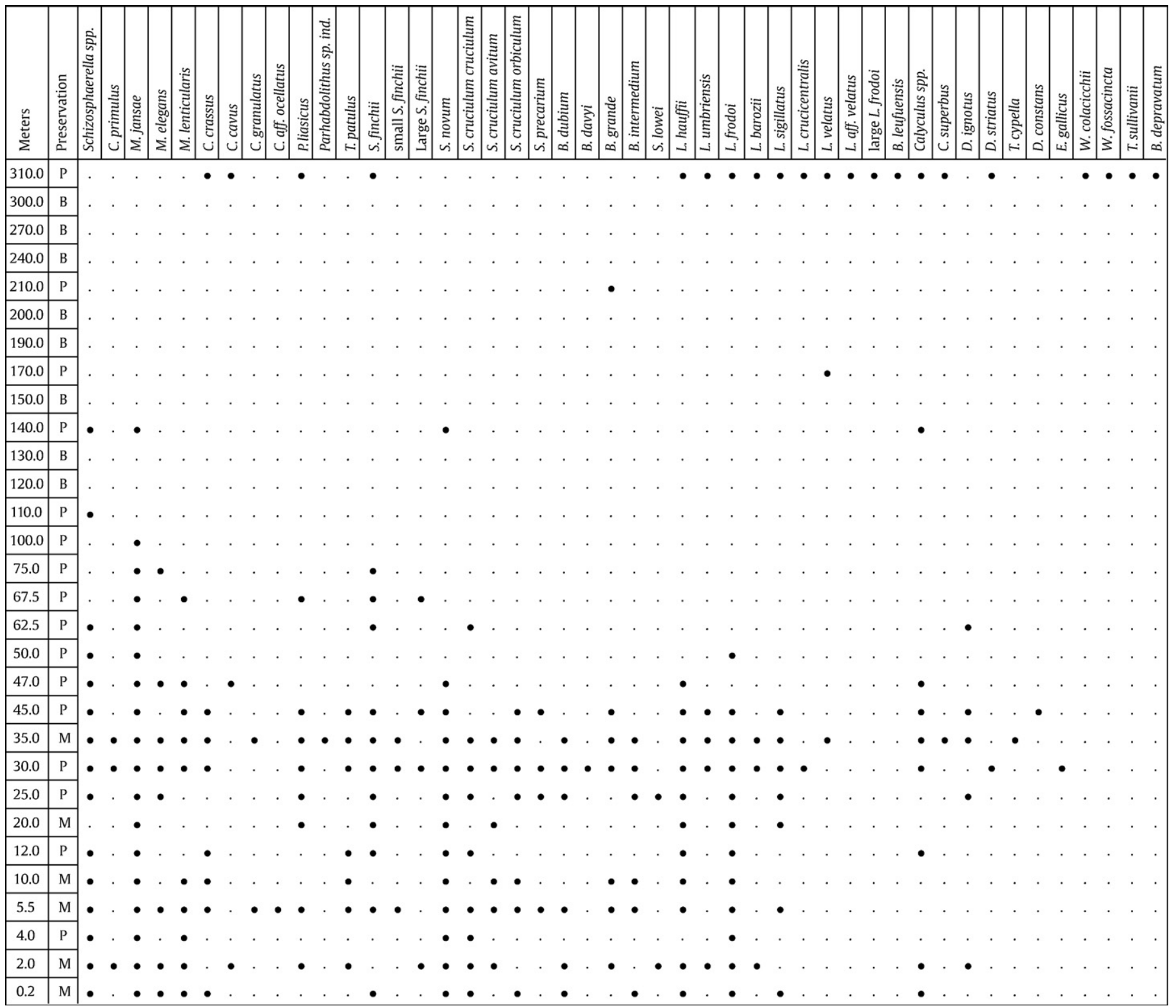

Polymorphum Zone (Fig. 6). An occurrence of D. ignotus earlier than in the literature has been similarly observed in the Peniche section (base of the Toarcian; Mattioli, personal observation). Apart from these anomalous occurrences, the presence of undisputable Carinolithus superbus specimens is observed at $35 \mathrm{~m}$, within the Polymorphum Zone. This stratigraphical event may actually correspond to the first occurrence of the species and, if so, the FO of C. superbus at Amellago is consistent with literature data (Mattioli and Erba, 1999). Another significant event, which is consistently recorded in the Levisoni (or Serpentinus) Zone in sections of the southern Tethyan margin (Mattioli and Erba, 1999), is the LO of Mitrolithus jansae. At Amellago, this event is observed at $140 \mathrm{~m}$. Samples in the interval between $\sim 70 \mathrm{~m}$ and $300 \mathrm{~m}$ are nearly barren for nannofossils. One sample at $310 \mathrm{~m}$ yielded Watznaueria fossacincta, W. colacicchii, Biscutum depravatum and Triscutum sullivanii. The first Watznaueria specimens are generally observed from the upper part of the Lower Toarcian (Mattioli and Erba, 1999). According to these authors, B. depravatum and T. sullivanii first occur in the late middle Toarcian.

\subsection{Carbon and oxygen isotopes}

The stable carbon isotope curve shows two negative shifts in the bottom part of the section, followed by a plateau during the upper Levisoni-lower Bifrons Zone and a twofold positive shift in the upper Bifrons-Gradata Zones (Table 2; Fig. 6). The first negative excursion is relatively sharp, starting at the boundary between the Ouchbis and Agoudim Formations $\left(\delta^{13} \mathrm{C}\right.$ values around $0.35 \%$ ) and reaches a minimum value of $-1.72 \%$. A gradual increase is thereafter observed in the Polymorphum Zone, with plateau values averaging $0.44 \%$. The sediment thickness recording this first negative excursion is ca. $35 \mathrm{~m}$. The subsequent second negative excursion starts at $70 \mathrm{~m}$. Values are decreasing less rapidly than for the first excursion, reaching a minimum of $-2.05 \%$ at $100 \mathrm{~m}$. This is followed by a positive shift, reaching $0.22 \%$ 。 at $140 \mathrm{~m}$ and a plateau centered on $0 \%$. The thickness of the second negative excursion is ca. $50 \mathrm{~m}$. The final positive excursion reaches the value of $1.71 \%$, with an average value of $0.75 \%$. The amplitude of the negative $\delta^{13} \mathrm{C}$ shifts is similar to those observed in the Peniche section in 
Table 2

Carbon and oxygen stable isotope results (\% VPDB) from the Amellago section.

\begin{tabular}{|c|c|c|c|c|c|}
\hline \multicolumn{3}{|c|}{ Performed in Liverpool } & \multicolumn{3}{|c|}{ Performed in Bochum } \\
\hline $\begin{array}{l}\text { Sample } \\
\text { height (m) }\end{array}$ & $\begin{array}{l}\delta^{13} \mathrm{C} \text { VPDB } \\
(\%)\end{array}$ & $\begin{array}{l}\delta^{18} \mathrm{O} \text { VPDB } \\
(\%)\end{array}$ & $\begin{array}{l}\text { Sample } \\
\text { height (m) }\end{array}$ & $\begin{array}{l}\delta^{13} \mathrm{C} \text { VPDB } \\
(\%)\end{array}$ & $\begin{array}{l}\delta^{13} \mathrm{O} \text { VPDB } \\
(\%)\end{array}$ \\
\hline 0.2 & 0.89 & -6.96 & 140 & 0.19 & -6.87 \\
\hline 2 & -0.11 & -4.37 & 160 & -0.06 & -6.26 \\
\hline 4 & 0.61 & -6.78 & 180 & 0.52 & -6.85 \\
\hline 5.5 & 0.01 & -6.10 & 200 & -0.28 & -6.72 \\
\hline 8 & -0.92 & -5.07 & 220 & 0.35 & -6.19 \\
\hline 10 & -1.72 & -5.25 & 240 & 0.07 & -6.71 \\
\hline 12 & -1.17 & -6.27 & 260 & -0.40 & -6.21 \\
\hline 15 & -0.99 & -5.78 & 280 & 0.25 & -6.18 \\
\hline 20 & -0.97 & -7.13 & 300 & 0.69 & -5.92 \\
\hline 25 & -1.06 & -5.34 & 320 & 1.68 & -6.40 \\
\hline 30 & -0.60 & -5.91 & 340 & 0.31 & -6.74 \\
\hline 32.5 & -0.65 & -5.72 & 360 & 0.13 & -6.88 \\
\hline 35 & -0.61 & -5.52 & 380 & 0.67 & -6.18 \\
\hline 39.4 & 0.14 & -5.95 & 395 & 1.23 & -6.24 \\
\hline 40 & -0.13 & -5.13 & 400 & 0.48 & -6.76 \\
\hline 41 & -0.39 & -6.09 & 420 & 0.35 & -6.72 \\
\hline 45 & -0.04 & -4.90 & 440 & -0.09 & -6.26 \\
\hline 47 & 0.63 & -5.81 & 460 & 0.20 & -6.00 \\
\hline 50 & 0.21 & -4.88 & 470 & 0.57 & -5.94 \\
\hline 56 & 0.61 & -6.14 & 480 & 0.24 & -5.95 \\
\hline 60 & 0.01 & -6.55 & 490 & 0.37 & -5.48 \\
\hline 62.5 & 0.46 & -6.42 & 500 & 0.37 & -5.88 \\
\hline 65 & 1.30 & -6.59 & 510 & -0.03 & -5.70 \\
\hline 67.5 & 0.16 & -6.80 & 520 & -0.40 & -5.86 \\
\hline 70 & 0.67 & -7.24 & 533 & -0.10 & -5.24 \\
\hline 75 & -0.59 & -6.12 & & & \\
\hline 80 & -1.19 & -5.73 & & & \\
\hline 87 & -0.85 & -5.42 & & & \\
\hline 90 & -0.99 & -5.18 & & & \\
\hline 100 & -2.05 & -4.72 & & & \\
\hline 110 & -1.26 & -6.34 & & & \\
\hline 120 & 0.01 & -6.51 & & & \\
\hline 130 & -0.13 & -6.00 & & & \\
\hline 140 & 0.22 & -6.73 & & & \\
\hline 150 & -0.63 & -6.15 & & & \\
\hline 170 & -0.20 & -6.68 & & & \\
\hline 190 & 0.05 & -6.54 & & & \\
\hline 210 & -0.04 & -5.96 & & & \\
\hline 230 & 0.15 & -6.32 & & & \\
\hline 250 & 0.43 & -6.14 & & & \\
\hline 270 & 0.13 & -6.03 & & & \\
\hline 290 & -0.84 & -6.43 & & & \\
\hline 310 & 1.38 & -6.14 & & & \\
\hline 330 & 1.71 & -6.30 & & & \\
\hline 350 & 0.26 & -6.30 & & & \\
\hline 370 & 0.67 & -5.98 & & & \\
\hline 390 & 0.88 & -5.87 & & & \\
\hline 410 & 1.18 & -5.95 & & & \\
\hline 430 & -0.21 & -5.93 & & & \\
\hline 450 & 0.24 & -5.78 & & & \\
\hline
\end{tabular}

bulk carbonate samples (Hesselbo et al., 2007) and brachipods (Suan et al., 2008a). The excursion is, however, twice the amplitude in organicrich European sections (e.g. Jenkyns and Clayton, 1997; Röhl et al., 2001). Higher fractionation between inorganic and organic carbon, or changes in the hydrological cycle, might be invoked to explain this difference (see Suan et al., 2008a).

Oxygen isotope results are displayed in Table 2 . The average value is around $-6 \%$. Minimums are observed in the lowermost and uppermost Polymorphum Zone $(-7.13 \%$ and $-7.24 \%$, respectively). The lower Levisoni Zone is characterized by a steady increase reaching $-4.72 \%$ 。 $(100 \mathrm{~m})$. A slightly increasing trend around $-6.2 \%$ 。 characterizes the upper part of the section. These values are very low compared to oxygen isotope values recovered from belemnite guards, brachiopod shells and fish teeth (McArthur et al., 2000; Bailey et al., 2003; Rosales et al., 2004; van de Schootbrugge et al., 2005; Gomez et al., 2008; Suan et al., 2008a; Dera et al., 2009a), indicating that they are not reliable as a temperature proxy, but most probably influenced by cements resulting from diagenetic burial or fresh water input (e.g. Röhl et al., 2001; Schmid-Röhl et al., 2002). Despite the alteration of the oxygen values, the carbon isotope values are likely to be of primary origin because they are in the same range of values and have a similar pattern to those found in the European sections (Jenkyns and Clayton, 1997; Röhl et al., 2001; Hesselbo et al., 2007; see also Marshall, 1992).

\subsection{Phosphorus content}

Two high-value intervals, in the lower Levisoni and upper Bifronslower Gradata Zones, respectively, characterize the phosphorus content curve of the Amellago section (Fig. 6). Intervals of relative low values are observed in the uppermost Pliensbachian, lower Bifrons and Bonarelli Zones. Despite the scatter in the later, the phosphorus average values for the Pliensbachian interval are relatively low (with an average of $270 \mathrm{ppm}$ ) and are followed by a rapid increase during the lower Polymorphum Zone with values averaging $360 \mathrm{ppm}$. An accelerating increase, reaching maximum values around $500 \mathrm{ppm}$, characterizes the upper Polymorphumlower Levisoni Zone. The maximum phosphorus values encountered in our survey are situated at the transition from the Bifrons to Gradata Zones, with values up to $672.7 \mathrm{ppm}$ and $954.4 \mathrm{ppm}$. The average value between $290 \mathrm{~m}$ and $440 \mathrm{~m}$ is $470 \mathrm{ppm}$. Even when the two extremely high values are not included in the calculation, the average value for this interval is still relatively high (424 ppm).

\subsection{Total organic carbon}

TOC measurements of 31 samples from ONHYM laboratories, Rabat (Morocco), between $12 \mathrm{~m}$ and $170 \mathrm{~m}$ revealed low absolute values (between $0.04 \%$ and $0.41 \%$ TOC). However, a clear trend occurs (Fig. 6): a gradual increase in TOC content from $12 \mathrm{~m}$ to $70 \mathrm{~m}$, followed by a sudden drop to low values. Additionally, 10 samples were measured by Geochemical Investigations Ltd, UK. They confirm the increase of TOC values around the Polymorphum-Levisoni boundary. One sample at $70 \mathrm{~m}$ has a relatively high TOC value of $3.24 \%$. A relative small increase in TOC values is also observed in the upper Middle Toarcian.

\section{Discussion}

5.1. Correlation with European sections and implications for the timing of Early Toarcian events

The high-resolution carbon isotope curve of the Peniche section (Fig. 7; Hesselbo et al., 2007) has shown that the Early Toarcian is characterized by the presence of two negative shifts, at the Pliensbachian-Toarcian boundary and upper Polymorphum-lower Levisoni Zones transition, respectively. The second excursion was already well known in carbonate and organic matter from other European sections and is characteristic of the T-OAE (Jenkyns and Clayton, 1997; Hesselbo et al., 2000; Schouten et al., 2000; Röhl et al., 2001; Schmid-Röhl et al., 2002; see also Cohen et al., 2007 for a review). The first "boundary" negative shift was also documented in brachiopods of the Peniche section by Suan et al. (2008a). In the Peniche section, the first excursion is of same amplitude as the T-OAE excursion. The two intervals are moreover both characterized by an increase in temperature, sea-level rise, a reduction of the nannofossil Schizosphaerella size (Suan et al., 2008a), and high extinction rates (Little and Benton, 1995; Vöros, 2002; Cecca and Macchioni, 2004; Wignall et al., 2005). These similarities led Suan et al. (2008a) to postulate that the same processes initiated them.

In the Amellago section, the two negative excursions are of equal stratigraphic thickness and amplitude. This observation confirms that the Pliensbachian-Toarcian boundary is characterized by a major 


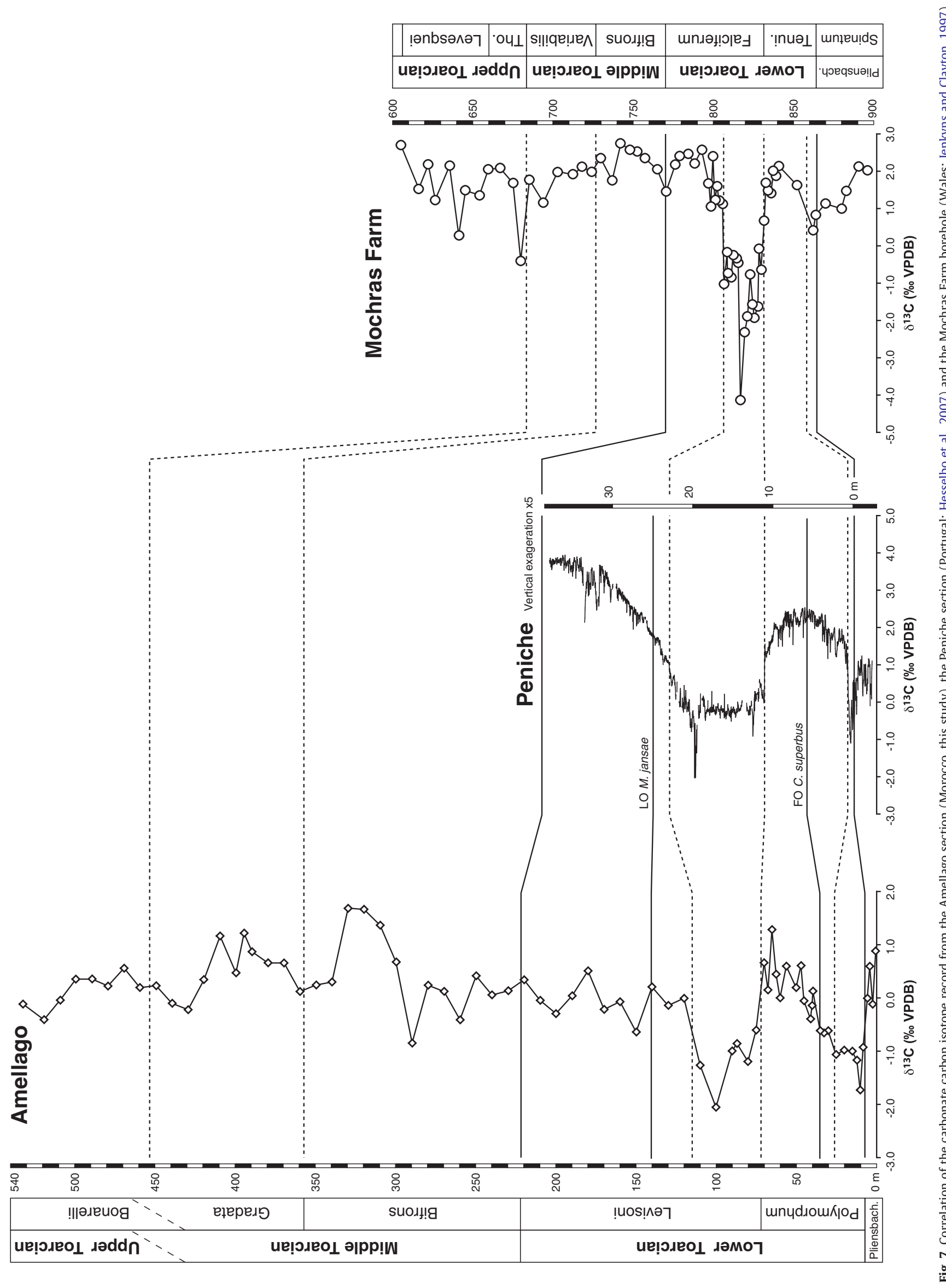


disturbance of the carbon cycle, which seems to be of equal intensity to as the T-OAE perturbation. In the British Isles, the PliensbachianToarcian boundary is also marked by the presence of a thin, pyriterich, black-shale interval, known as the Sulphur Band (Wignall and Bond, 2008), indicating that this event is locally associated with anoxic bottom water. This first negative carbon isotope shift has recently been identified at the Hawsker Bottoms section, England (Littler et al., 2010). A small negative carbon isotope shift may also be observed in the record from the Mochras Farm borehole (Fig. 7; Jenkyns and Clayton, 1997). This shift may however not be present everywhere due to the presence of a "boundary" hiatus in some parts of Northern European realm (Guex et al., 2001; Morard et al., 2003; Wignall and Bond, 2008; Mailliot et al., 2009).

As shown by Littler et al. (2010), it is however likely that, when present in European sections, this first negative shift would be recorded in a very thin interval. This can be interpreted either as the result of a short-lived event or a sedimentary condensation. The fact that in Amellago the "boundary" shift is of comparable thickness (ca. $30 \mathrm{~m}$ ) as the T-OAE shift would argue that many other sections are very condensed. At Amellago, there is no indication of a drastic change in sedimentation regime, and therefore increased sedimentation rate, in the marls of the Agoudim Fm, which could explain a relatively important dilatation of its basal part. Despite the fact that the Polymorphum Zone is characterized by an increased occurrence of fine-grained turbidites compared to the Levisoni Zone (Fig. 6) within the ubiquitous green marl sediments, they only account for ca. $4 \mathrm{~m}$ of the total sediment column. As the thickness of the Levisoni Zone is $73 \mathrm{~m}$, this cannot account for a significant increase in the overall sedimentation rate. The condensed Pliensbachian-Toarcian boundary interval in European sections could be related to the sharp regressivetransgressive sea-level fluctuation occurring during this time (Suan et al., 2008a; Wignall and Bond, 2008).

Assuming that there is no major change in sedimentation rate in the Amellago section, the comparable thickness of the two negative carbon isotope excursions would thus suggest that their duration is similar. This idea could perhaps be tested in the future by a detailed cyclostratigraphic study. An alternative suggestion would be that local palaeoceanographic factors may have given rise to a longer relaxation period of the oceanic carbon reservoir after the initial perturbation. This seems unlikely without a mechanism that can account for differential relaxation process. Suan et al. (2008a) suggested that a double input of isotopically light carbon into the oceanic-atmospheric system, related to two successive phases of the Karoo-Ferrar large igneous province, was likely the cause of this repeated palaeoenvironmental perturbation.

Jarvis et al. (2006; see also Wilmsen, 2007) have observed a positive relationship between carbon isotope stratigraphy and change in sealevel during the Late Cretaceous. They propose that sea-level fall exposes isotopically light shelf sediment to erosion, inducing a negative $\delta^{13} \mathrm{C}$ excursion in marine sediments. During the following transgression, coastal lowlands rich in nutrients are flooded inducing increased productivity and thus a positive $\delta^{13} \mathrm{C}$ excursion. A sea-level fall followed by rapid flooding has been associated with the Pliensbachian-Toarcian boundary interval (Wilmsen and Neuweiler, 2008; Suan et al., 2010). Favourable conditions for this scenario are therefore present to explain the observed carbon isotope trend during this time interval in the marine bulk-rock record. However, this scenario fails to explain why the same $\delta^{13} \mathrm{C}$ negative shifts are recorded in the atmospheric reservoir $\left(\delta^{13} \mathrm{C}\right.$ in terrestrial wood for both negative excursions; Hesselbo et al., 2000, 2007; Littler et al., 2010).

5.2. Enhanced nutrient levels associated with carbon isotope negative shifts

The Toarcian OAE has been interpreted to be the result of increased nutrient levels and primary productivity, via an accelerated hydro- logical cycle and/or intensified wind-driven upwelling (Jenkyns, 2003; Erba, 2004). Increased nutrient levels have been proposed following the observation of a decrease in the relative abundance of Schizosphaerella near the Pliensbachian-Toarcian boundary (Erba, 2004). Suan et al. (2008a) have extended this model to the earliest Toarcian event (corresponding to the "boundary" carbon isotope excursion) and proposed a twofold increase in nutrient levels, coeval with temperature rise and culminating during the T-OAE. They have based this interpretation on the twofold diminution of Schizosphaerella size, during the lower Polymorphum and lower Levisoni Zone, respectively. On the basis of nannofossil assemblages, Mattioli et al. (2008) infer high surface water fertility in the interval below the isotope excursion of the T-OAE. In fact, they notice a high occurrence of mesotrophic taxa (namely Biscutaceae such as S. novum and $S$. finchii; Mattioli and Pittet, 2004; Tremolada et al., 2005). A similar trend is observed in the Amellago section (Fig. 6). However, both in the Mattioli et al. (2008) paper and in this work, the proportion of Schizosphaerella is still relatively high during most of the Polymorphum Zone. On this evidence, changes in nutrient concentration during the Early Toarcian are therefore still partly equivocal.

In order to trace the Toarcian nutrient level changes in the Amellago section, bulk-rock phosphorus content was investigated. Phosphorus represents an essential nutrient for living organisms and it has been proposed as the main biolimiting factor on geological time scale (Tyrrell, 1999). Its distribution in sediments has been successfully used to constrain nutrient levels in past oceans (Föllmi, 1995, 1996; van de Schootbrugge et al., 2003; Bodin et al., 2006; Mort et al., 2007) but to our knowledge, this proxy has however never been applied to Toarcian sediments. The amount of phosphorus in sediment is controlled by the rate of phosphorus delivery to the ocean, the degree of bottom water oxygenation and the sediment accumulation rate (see Bodin et al., 2006, for a review). As such, increased continental weathering, increased bottom water oxygenation or sediment condensation, tend to increase phosphorus concentration in sediments. Bottom water oxygenation, and especially the lack of bottom water oxygen (anoxic event) can be recognized by sedimentological criteria (absence or presence of fine, non-bioturbated, laminations) or organic matter accumulation. The absence of laminated black-shales and low absolute TOC values in the Amellago section, suggest an absence of bottom water anoxia in the Moroccan deep-water setting. This observation confirms the regional character, rather than global nature, of the Early Toarcian anoxic event (Baudin et al., 1990; McArthur et al., 2008a). Moreover, no condensed horizon has been observed in this section.

Sedimentation rates are difficult to calculate precisely for short time intervals and largely depend on the time scale adopted. In the absence of a high-resolution time scale calibrated by bentonite layers, cyclostratigraphy can be used to estimate sedimentation rate and thus phosphorus accumulation rate (Bodin et al., 2006). A cyclostratigraphic scheme is presently only available for the earliest Toarcian (Suan et al., 2008b; Sabatino et al., 2009), but when used to calculate phosphorus accumulation rate for that time period at the Amellago section, no change is observed.

The present results show a direct link between phosphorus content and the carbon isotope curve during the Early Toarcian (Fig. 6). The long-term trend is characterized by a continuous increase in phosphorus content. Moreover, both $\delta^{13} \mathrm{C}$ negative shifts are associated with a rapid increase in phosphorus content. These results are in agreement with the model of Suan et al. (2008a) postulating a twofold increase in nutrient level, coeval with the PliensbachianToarcian boundary and Early Toarcian negative carbon excursions. Wilmsen and Neuweiler (2008) have observed a change from semiarid to humid climate at the Pliensbachian-Toarcian boundary, accompanied by an increased input of terrigenous material from fluviodeltaic runoff. Such a change could be the cause of the increased amount of phosphorus delivery observed in our results. The increased 
nutrient levels during the Early Toarcian could however also be linked to a global increase in oceanic phosphorus content, such as those observed by Föllmi (1995) during the last 160 myr.

Cohen et al. (2004) reported an ${ }^{187} \mathrm{Os} /{ }^{188}$ Os excursion during the Toarcian OAE and suggested that this was linked to a 400 to $800 \%$ sudden increase in global weathering at the Tenuicostatum-Falciferum Zone transition, i.e. the base of the second negative carbon isotope shift of the Early Toarcian. Waltham and Gröcke (2006) and McArthur and Wignall (2007) however questioned the validity of such a dramatic increase of weathering rate. As noted earlier, the transition from the Pliensbachian to the Toarcian in the Amellago region is marked by increased terrigenous influx (Wilmsen and Neuweiler, 2008; and own observations in the Amellago section). Such an increase can be recognized throughout the Central High Atlas Basin (El Kamar et al., 1997-1998; Souhel et al., 1998; Ettaki and Chellai, 2005). It is however not observed in the Middle Atlas (e.g. Bejjaji et al., 2010). Wilmsen and Neuweiler (2008) interpret this change as a signature of climate change around the PliensbachianToarcian boundary, from semi-arid towards more humid conditions, leading to increased weathering rates. Suan et al. (2010) propose that the Pliensbachian-Toarcian boundary is associated with the change from an icehouse to a greenhouse state of the Earth. Such global change may have induced adjustment of climate belts, ultimately responsible for the increased terrigenous material input in the High Atlas. However, no drastic increase in terrigenous material input can be observed at the Polymorphum-Levisoni Zone transition in the High Atlas Basin (cf. Fig. 6; see also El Kamar et al., 1997-1998; Souhel et al., 1998; Ettaki and Chellai, 2005) so there is no evidence for the dramatic increase in weathering rate accompanying the second negative $\delta^{13} \mathrm{C}$ shift proposed by Cohen et al. (2004; see also McArthur et al., 2008b).

\subsection{Platform drowning event}

A ubiquitous drowning event at the Pliensbachian-Toarcian boundary is documented in the High Atlas (Warme, 1988; Blomeier and Reijmer, 1999; Fedan, 1999; Wilmsen and Neuweiler, 2008; Lachkar et al., 2009). This event is recognized on the margin of the basin by the transition from carbonate platform deposits (constituted by corals, calcareous green algae, gastropods, bivalves and small benthic foraminifera, representing a photozoan-dominated assemblage) to a condensed sequence made of low-diversity assemblages of echinoderms, brachiopods and bivalves, and ferruginous crusts, overlain by silty marls (Blomeier and Reijmer, 1999; Fedan, 1999; Wilmsen and Neuweiler, 2008). In basinal settings, it is marked by the replacement of the limestone-marl alternations of the Ouchbis Formation by silty marls of the Tagoudite or Agoudim Formations. A link with Early Toarcian palaeoenvironmental perturbation has already been proposed by these authors to explain this drowning event in the High Atlas.

The drowning of a carbonate platform can occur by reduction of its growth potential (Schlager, 1981). Nutrient excess is one of the environmental factors that can reduce it (Hallock and Schlager, 1986). Moreover, the type of carbonate platform present during the Late Pliensbachian in the High Atlas (i.e. photozoan-dominated communities, with scleractinian corals, green algae and large bivalves) is susceptible to nutrient excess because it would have been highly adapted to oligotrophic waters (Wilmsen and Neuweiler, 2008). Due to the coeval timing of these two events, we thus propose that the drowning of the High Atlas Basin carbonate platforms at the Pliensbachian-Toarcian boundary was induced by an increase in nutrient levels in the sea, ultimately linked to the global Early Toarcian palaeoenvironmental perturbations. Additionally, a dramatic increase in seawater temperature at the Pliensbachian-Toarcian boundary (Dera et al., 2009a) may also have contributed to weaken the benthic community and facilitate the demise of the carbonate platform factory. Similar impact of the Early Toarcian palaeoenvironmental changes on carbonate platforms are also recorded in other Tethyan localities (Jenkyns, 1988; Bassoullet and Baudin, 1994; Cobianchi and Picotti, 2001; Woodfine et al., 2008).

\subsection{A middle Toarcian event?}

Stratigraphic changes in carbon isotope and phosphorus content at Amellago show a pronounced positive shift during the upper Bifrons Zone, followed by a second, less important one in the Gradata Zone. Positive shifts of carbon isotope values are usually interpreted as reflecting enhanced primary productivity and organic matter preservation (Broecker and Peng, 1982; Arthur et al., 1987; Weissert, 1989; Weissert et al., 1998). Due to the preferential uptake of ${ }^{12} \mathrm{C}$ by photosynthetic organisms, high phytoplankton productivity will lead to ${ }^{13} \mathrm{C}$-enriched surface water. This is then recorded by the $\delta^{13} \mathrm{C}$ of calcareous shells from the organisms living in these waters and which compose the carbonate bulk-rock. However, another explanation for a positive shift in basinal bulk carbonate $\delta^{13} \mathrm{C}$ is given by Föllmi et al. (2006). These authors suggest that changes in the shedding of carbonate platform mud can also influence basin bulk-rock $\delta^{13} \mathrm{C}$. Depending on the type of carbonate factory developing next to the basin, and thus the relative proportion of aragonite-producing organisms compared to calcite-producing ones, the mud produced on the platform will have a different $\delta^{13} \mathrm{C}$ signature (Swart and Eberli, 2005). Basinal bulk-rock carbonate is a mixture of pelagic and exported platform mud. A significant change in carbonate platform factory can thus change basin bulk-rock $\delta^{13} \mathrm{C}$ (Bartolini et al., 2003). According to Bartley and Kah (2004), the amount of dissolved inorganic carbon (DIC) in seawater is also important because it acts as a buffer on the $\delta^{13} \mathrm{C}$ signal. Thus, the more DIC in the ocean, the less sensitive the marine $\delta^{13} \mathrm{C}$ system to changes in the carbon cycle. The recognition of a $\delta^{13} \mathrm{C}$ positive shift in basinal bulk-rock carbonate is thus not sufficient to speculate on increased primary productivity.

Nevertheless, the upper Bifrons-lower Gradata Zones interval is clearly associated with a positive shift in bulk-rock phosphorus content (Fig. 7), indicating an increased nutrient delivery to the High Atlas Basin during this time interval. This could have lead to increased primary productivity. Moreover, despite low measured values, the TOC data from this time interval show a relative increase, that could be linked to enhanced organic matter production. The combination of these three proxies is thus pointing toward an increased palaeoproductivity event during the middle Toarcian in the High Atlas. Interestingly, Dera et al. (2010) have also observed that this interval was characterized by an ammonite extinction event in the Tethyan realm.

Only a few studies have documented carbon isotope trends in the middle and Late Toarcian. Jenkyns and Clayton (1997) and Jenkyns et al. (2001) have documented bulk-rock and organic $\delta^{13} \mathrm{C}$ in the Mochras Farm (Wales; Fig. 7) and Winterborne Kingston (England) boreholes. High values of bulk carbonate $\delta^{13} \mathrm{C}$ are observed within the upper Bifrons Zone. These high $\delta^{13} \mathrm{C}$ values are however not observed in the organic matter. Gomez et al. (2008) have documented belemnite $\delta^{13} \mathrm{C}$ values from Central and Northern Spain. Following a short-lived negative shift, a positive shift of the $\delta^{13} \mathrm{C}$ curve in the upper Bifrons-lower Gradata Zones can be observed. Our dataset apparently shows the same configuration. The negative shift is however only documented by one data point (at $290 \mathrm{~m}$ ) so no definitive conclusions can be drawn. Further detailed studies are needed to better understand this middle Toarcian event and assess if it is a local or global feature.

\section{Conclusions}

The carbon isotope curve obtained from the Amellago section (High Atlas, Morocco) displays two distinct negative shifts of similar 
amplitude (between 2\% and 2.5\% variation), occurring at the Pliensbachian-Toarcian boundary and during the Lower Toarcian Levisoni Zone, respectively. These two shifts are correlated to the ones observed in well-documented European sections and thus further confirm the supra-regional nature of perturbation in the oceanic carbon cycle during the latest Pliensbachian-Early Toarcian interval. Contrary to the European sections, the thickness of the sediments bearing these excursions are similar and very thick (more than $30 \mathrm{~m}$ ), indicating that the first "boundary" negative excursion is inadequately recorded in highly condensed sediments in Europe. A positive carbon isotope shift is also recorded during the middle Toarcian.

Phosphorus content of the bulk-rock was used to trace palaeonutrient levels in the Amellago section. The Lower Toarcian is characterized by a twofold increase of phosphorus content, coeval to the two negative carbon isotope excursions, documenting enhanced nutrient delivery to the sea during the Polymorphumearliest Levisoni Zone. This nutrient level increase is moreover interpreted to be responsible for the drowning of the High Atlas photozoan carbonate platform at the Pliensbachian-Toarcian boundary. After a decrease in phosphorus levels, a second shift toward high values is documented in the middle Toarcian, around the BifronsGradata Zone boundary. This interval of relatively high nutrient levels is coeval with the middle Toarcian positive carbon isotope excursion and a slight increase in TOC values, pointing toward an increased primary productivity during this time interval. A potential middle Toarcian event is thus recorded in the High Atlas. Further studies are necessary to determine if this event is present elsewhere.

\section{Acknowledgments}

This study was funded by the North Africa Research Group (University of Manchester), sponsored by Maersk Oil, Hess, Anadarko, BG, Pluspetrol, Oxy, Wintershall, Repsol, RWE, Petro-Canada, Woodside and ConocoPhilips. It was initiated by a field campaign in the High Atlas Mountains of Morocco in September and October 2007 undertaken by NARG for Maersk Oil. We are especially grateful to the Office National des Hydrocarbures et des Mines (ONHYM) for organising logistics. Geochemical sample analysis by A. Chakor Alami and further support by A. Ait Salem and M. Nahim (all ONHYM) is gratefully acknowledged. Further TOC analyses were undertaken by Peter Walko of Geochemical Investigations Ltd UK. The first author would like to acknowledge Stéphane Westermann, Melody Stein and Karl Föllmi (University of Lausanne) for their help with the phosphorus analyses. Paula Desvignes is thanked for her help in preparation of nannofossil analysis samples. Stable isotope analyses were carried out by Jim Ball (University of Liverpool) and Ulrike Schulte (University of Bochum). We are grateful to Finn Surlyk, Markus Wilmsen and an anonymous reviewer for their detailed comments on this manuscript.

\section{References}

Arthur, M.A., Schlanger, S.O., Jenkyns, H.C., 1987. The Cenomanian-Turonian Oceanic Anoxic Event, II. Palaeoceanographic controls on organic-matter production and preservation. In: Brooks, J., Fleet AJ. (Eds.), Marine petroleum source rocks: Geological Society of London, Special Publication, 26, pp. 401-420.

Baccelle, L., Bosellini, A., 1965. Diagrammi per la stima visiva della composizione percentuale nelle rocce sedimentarie. Annali dell'Universita di Ferrara, Scienze Geologiche e Paleontologiche 1,59-62.

Bailey, T.R., Rosenthal, Y., McArthur, J.M., van de Schootbrugge, B., Thirlwall, M.F., 2003. Paleoceanographic changes of the Late Pliensbachian-Early Toarcian interval: a possible link to the genesis of an Oceanic Anoxic Event. Earth and Planetary Science Letters 212, 307-320.

Bartley, J.K., Kah, L.C., 2004. Marine carbon reservoir, $\mathrm{C}_{\text {org }}-\mathrm{C}_{\text {carb }}$ coupling, and the evolution of the Proterozoic carbon cycle. Geology 32, 129-132.

Bartolini, A., Pittet, B., Mattioli, E., 2003. Shallow-platform palaeoenvironmental conditions recorded in deep-shelf sediments: $\mathrm{C}$ and $\mathrm{O}$ stable isotopes in Upper Jurassic sections of southern Germany (Oxfordian-Kimmeridgian). Sedimentary Geology 160, 107-130.
Bassoulet, J.-P., Elmi, S., Poisson, F., Cecca, F., Belion, Y., Guiraud, R., Baudin, F., 1993. Mid Toarcian. In: Dercourt, J., Ricou, L.E., Vrielynck, B. (Eds.), Atlas Tethys, Paleoenvironmental Maps: Becip-Franlab, Rueil-Malmaison, France, pp. 63-80.

Bassoullet, J.P., Baudin, F., 1994. Le Toarcien inférieur: une période de crise dans les bassins et sur les plate-formes carbonatées de l'Europe du Nord-Ouest et de la Téthys. Geobios 17, 645-654.

Baudin, F., Herbin, J.-P., Vandenbroucke, M., 1989. Mapping and geochemical characterization of the Toarcian organic matter in the Mediterranean Tethys and Middle East. Organic Geochemistry 16, 677-687.

Baudin, F., Herbin, J.P., Bassoullet, J.P., Dercourt, J., Lachkar, G., Manivit, H., Renard, M., 1990. In: Huc, Y. (Ed.), Distribution of organic matter during the Toarcian in the Mediterranean Tethys and Middle East: Depostion of Organic Facies, AAPG Studies in Geology, 30, pp. 73-92.

Bejjaji, Z., Chakiri, S., Reolid, M., Boutakiout, M., 2010. Foraminiferal biostratigraphy of the Toarcian deposits (Lower Jurassic) from the Middle Atlas (Morocco). Comparison with western Tethyan areas. Journal of African Earth Sciences 57, 154-162.

Blomeier, D.P.G., Reijmer, J.J.G., 1999. Drowning of a Lower Jurassic Carbonate Platform: Jbel Bou Dahar, High Atlas, Morocco. Facies 41, 81-110.

Bodin, S., Godet, A., Föllmi, K.B., Vermeulen, J., Arnaud, H., Strasser, A., Fiet, N., Adatte, T. 2006. The Late Hauterivian Faraoni oceanic anoxic event in the western Tethys: evidence from phosphorus burial rates. Palaeogeography, Palaeoclimatology, Palaeoecology 235, 245-264.

Bourillot, R., Neige, P., Pierre, A., Durlet, C., 2008, Early-Middle Jurassic Lytoceratid ammonites with constrictions from Morocco: palaeobiogeographical and evolutionary implications. Palaeontology 51, 597-609.

Broecker, W.S. Peng, T.-H., 1982. Tracers in the sea. Lamont-Doherty Geologica Observatory, Columbia University, Palisades, New-York, Eldigio Press. pp. 690.

Cecca, F., Macchioni, F., 2004. The two Early Toarcian (Early Jurassic) extinction events in ammonoids. Lethaia 37, 35-56.

Cobianchi, M., Picotti, V., 2001. Sedimentary and biological response to sea-level and palaeoceanographic changes of a Lower-Middle Jurassic Tethyan platform margin (Southern Alps, Italy). Palaeogeography, Palaeoclimatology, Palaeoecology 169, 219-244.

Cohen, A.S., Coe, A.L., Harding, S.M., Schwark, L., 2004. Osmium isotope evidence for the regulation of atmospheric $\mathrm{CO}_{2}$ by continental weathering. Geology 32, 157-160.

Cohen, A.S., Coe, A.L., Kemp, D.B., 2007. The Late Palaeocene-Early Eocene and Toarcian (Early Jurassic) carbon isotope excursions: a comparison of their time scales, associated environmental changes, causes and consequences. Journal of the Geological Society of London 164, 1093-1108.

Dera, G., Pucéat, E., Pellenard, P., Neige, P., Delsate, D., Joachimski, M.M., Reisberg, L., Martinez, M., 2009a. Water mass exchange and variations in seawater temperature in the NW Tethys during the Early Jurassic: evidence from neodymium and oxygen isotopes of fish teeth and belemnites. Earth and Planetary Science Letters 286, 198-207.

Dera, G., Pellenard, P., Neige, P., Deconinck, J.-F., Pucéat, E., Dommergues, J.-L., 2009b. Distribution of clay minerals in Early Jurassic Peritethyan seas: palaeoclimatic significance inferred from multiproxy comparisons. Palaeogeography, Palaeoclimatology, Palaeoecology, 271, pp. 39-51.

Dera, G., Neige, P., Dommergues, J.-L., Fara, E., Laffont, R., Pellenard, P., 2010. Highresolution dynamics of Early Jurassic marine extinctions: the case of PliensbachianToarcian ammonites (Cephalopoda). Journal of Geological Society of London 167, 21-33.

Dromart, G., Allemand, P., Garcia, J.-P., Robin, C., 1996. Variation cyclique de la production carbonatée au Jurassique le long d'un transect Bourgogne-Ardèche, EFrance. Bulletin de la Société Géologique de France. 167, 423-433.

Du Dresnay, R., 1971. Extension et developpement des phenomenes recifaux jurassique dans le domaine atlasique marocain, particulierement au Lias moyen. Bulletin de la Société Géologique de France 13, 46-56.

Eaton, A.D., Clesceri, L.S., Greenberg, A.E., 1995. Standard methods for the examination of water and wastewater, 19th edition. American Public Health Association, New-York

El Kamar, A., Boutakiout, M., Elmi, S., Sadki, D., Ruget, C., 1997-1998. Foraminifères et ostracodes du Lias supérieur et du Bajocien de la Ride de Talghemt (Haut-Atlas central, Maroc). Bulletin de l'Institut Scientifique de Rabat 21, 31-41.

Erba, E., 2004. Calcareous nannofossils and Mesozoic oceanic anoxic events. Marine Micropaleontology 52, 85-106.

Ettaki, M., Chellai, E.H., 2005. Le Toarcien inferieur du Haut Atlas de Todrha-Dades (Maroc): sedimentologie et lithostratigraphie. Comptes Rendus Geosciences 337, 814-823.

Fedan, B., 1999. Le Jurassique du domaine des chaines Atlasiques marocaines illustré par la transversale Meknes-Boulemane-Midelt-Errachidia. Premier Colloque National sur le Jurassique Marocain. Field Guide. Moroccan Association of Petroleum Geologists. pp. 142.

Föllmi, K.B., 1995. 160 m.y. record of marine sedimentary phosphorus burial: coupling of climate and continental weathering under greenhouse and icehouse conditions. Geology 23, 859-862.

Föllmi, K.B., 1996. The phosphorus cycle, phosphogenesis and marine phosphate-rich deposits. Earth-Science Reviews 40, 55-124.

Föllmi, K.B., Godet, A., Bodin, S., Linder, P., 2006. Interactions between environmental change and shallow-water carbonate build-up along the northern Tethyan margin and their impact on the early Cretaceous carbon-isotope record. Paleoceanography 21, PA4211.

Gomez, J.J., Goy, A., Canales, M.L., 2008. Seawater temperature and carbon isotope variations in belemnites linked to mass extinction during the Toarcian (Early Jurassic) in Central and Northern Spain. Comparison with other European sections. Palaeogeography, Palaeoclimatology, Palaeoecology 258, 28-58. 
Guex, J., Morard, A., Bartolini, A., Morettini, E., 2001. Découverte d'une importante lacune stratigraphique à la limite Domérien-Toarcien: implication paléo-océanographiques. Bulletin de la Société Vaudoise des Sciences Naturelles 345, 277-284.

Hadri, M., 1997. Carte géologique du Maroc: Tinejdad, échelle 1/100, 000. Notes et Mémoires du Service Géologique du Maroc $n^{\circ} 385$.

Hallock, P., Schlager, W., 1986. Nutrient excess and the demise of coral reefs and carbonate platforms. Palaios 1, 389-398.

Harries, P.J., Little, C.T.S., 1999. The early Toarcian (Early Jurassic) and the CenomanianTuronian (Late Cretaceous) mass extinctions: similarities and contrasts. Palaeogeography, Palaeoclimatology, Palaeoecology 154, 39-66.

Hesselbo, S.P., Gröcke, D.R., Jenkyns, H.C., Bjerrun, C.J., Farrimond, P., Morgans Bell, H.S., Green, O.R., 2000. Massive dissociation of gas hydrate during a Jurassic oceanic anoxic event. Nature 406, 392-395.

Hesselbo, S.P., Jenkyns, H.C., Duarte, L.V., Oliveira, L.C.V., 2007. Carbon-isotope record of the Early Jurassic (Toarcian) Oceanic Anoxic Event from fossil wood and marine carbonate (Lusitanian Basin, Portugal). Earth and Planetary Science Letters 253, 455-470.

Jacobshagen, V., 1988. The Atlas system of Morocco - studies on its geodynamic evolution. : Lecture Notes in Earth Science, 15. Springer Verlag, Berlin, p. 499.

Jarvis, I., Gale, A.S., Jenkyns, H.C., Pearce, M.A., 2006. Secular variation in Late Cretaceous carbon isotopes: a new $\delta^{13} \mathrm{C}$ carbonate reference curve for the CenomanianCampanian (99.6-70.6 Ma). Geological Magazine 143, 561-608.

Jenkyns, H.C., 1985. The Early Toarcian and Cenomanian-Turonian anoxic events in Europe: comparisons and contrasts. Geologische Rundschau 74, 505-518.

Jenkyns, H.C., 1988. The Early Toarcian (Jurassic) Anoxic Event: stratigraphy, sedimentary, and geochemical evidence. American Journal of Science 288, $101-151$

Jenkyns, H.C., 2003. Evidence for rapid climate change in the Mesozoic-Palaeogene greenhouse world. Philosophical Transactions of the Royal Society, London, Serie A 361, 1885-1916.

Jenkyns, H.C., Clayton, C.J., 1997. Lower Jurassic epicontinental carbonates and mudstones from England and Wales: chemostratigraphic signals and the early Toarcian anoxic event. Sedimentology 44, 687-706

Jenkyns, H.C., Gröcke, D.R., Hesselbo, S.P., 2001. Nitrogen isotope evidence for water mass denitrification during the Early Toarcian (Jurassic) oceanic anoxic event. Paleoceanography 16, 593-603.

Kemp, D.B., Coe, A.L., Cohen, A.S., Schwark, L., 2005. Astronomical pacing of methane release in the Early Jurassic period. Nature 437, 396-400.

Küspert, W., 1982. In: Einsele, S., Seilacher, A. (Eds.), Environmental change during oil shale deposition as deduced from stable isotope ratios.: Cyclic and event stratification. Springer-Verlag, Berlin, pp. 482-501.

Lachkar, N., Guiraud, M., El Harfi, A., Dommergues, J.-L., Dera, G., Durlet, C., 2009. Early Jurassic normal faulting in a carbonate extensional basin: characterization of tectonically driven platform drowning (High Atlas rift, Morocco). Journal of Geological Society of London 166, 413-430.

Laville, E., Pique, A., Amrhar, M., Charroud, M., 2004. A restatment of the Mesozoic Atlasic rifting (Morocco). Journal of African Earth Sciences 38, 145-153.

Little, C.T.S., Benton, M.J., 1995. Early Jurassic mass extiction: a global long-term event. Geology 23, 495-498.

Littler, K., Hesselbo, S.P., Jenkyns, H.C., 2010. A carbon-isotope perturbation at the Pliensbachian-Toarcian boundary: evidence from the Lias Group, NE England. Geological Magazine 147, 181-192.

Mailliot, S., Mattioli, E., Bartolini, A., Baudin, F., Pittet, B., Guex, J., 2009. Late Pliensbachian-Early Toarcian (Early Jurassic) environmental changes in an epicontinental basin of NW Europe (Causses area, central France): a micropaleontological and geochemical approach. Palaeogeography, Palaeoclimatology, Palaeoecology 273, 346-364.

Marshall, J.D., 1992. Climatic and oceanographic isotopic signals from the carbonate rock record and their preservation. Geological Magazine 129, 143-160.

Mattioli, E., Erba, E., 1999. Synthesis of calcareous nannofossil events in Tethyan Lower and Middle Jurassic successions. Riv. Ital. Paleontol. Stratigr. 105, 343-376.

Mattioli, E., Pittet, B., 2002. Contribution of calcareous nannoplankton to carbonate deposition: a new approach applied to the Lower Jurassic of central Italy. Marine Micropaleontology 45, 175-190.

Mattioli, E., Pittet, B., 2004. Spatial and temporal distribution of calcareous nannofossils along a proximal-distal transect in the Lower Jurassic of the Umbria-Marche Basin (central Italy). Palaeogeography, Palaeoclimatology, Palaeoecology 205, 295-316.

Mattioli, E., Pittet, B., Bucefalo Palliani, R., Röhl, H.-J., Schmid-Röhl, A., Morettini, E., 2004. Phytoplankton evidence for timing and correlation of palaeoceanographical changes during the Early Toarcian oceanic anoxic event (Early Jurassic). Journal of Geological Society of London 161, 685-693.

Mattioli, E., Pittet, B., Suan, G., Mailliot, S., 2008. Calcareous nannoplankton changes across the early Toarcian oceanic anoxic event in the western Tethys. Paleoceanography 23, PA3208.

McArthur, J.M., Wignall, P.B., 2007. Comment on “Non-uniqueness and interpretation of the seawater ${ }^{87} \mathrm{Sr} /{ }^{86} \mathrm{Sr}$ curve" by Dave Waltham and Darren R. Gröcke (GCA, 70, 2006, 384-394). Geochimica et Cosmochimica Acta 71, 3382-3386.

McArthur, J.M., Donovan, D.T., Thirlwall, M.F., Fouke, B.W., Mattey, D., 2000. Strontium isotope profile of the early Toarcian (Jurassic) oceanic anoxic event, the duration of ammonite biozones, and belemnite palaeotemperatures. Earth and Planetary Science Letters 179, 269-285.

McArthur, J.M., Algeo, T.J., Van de Schootbrugge, B., Li, Q., Howarth, R.J., 2008a. Basinal restriction, black shales, Re-Os dating, and the Early Toarcian (Jurassic) oceanic anoxic event. Paleoceanography 23, PA4217.

McArthur, J.M., Cohen, A.S., Coe, A.L., Kemp, D.B., Bailey, R.J., Smith, D.G., 2008b. Discussion on the Late Palaeocene-Early Eocene and Toarcian (Early Jurassic) carbon isotope excursions: a comparison of their time scales, associated environmental changes, causes and consequences. Journal, Vol. 164, 2007, 1093 1108. Journal of the Geological Society of London 165, 875-880.

McCrea, J.M., 1950. On the isotopic chemistry of carbonates and a paleotemperature scale. Journal of Chemical Physics 18, 849-857.

McElwain, J.C., Wade-Murphy, J., Hesselbo, S.P., 2005. Changes in carbon dioxide during an oceanic anoxic event linked to intrusion into Gondwana coals. Nature 435, 479-482.

Michard, A., 1976. Eléments de géologie Marocaine. Notes et Mémoires du Service Géologique 252, 408.

Morard, A., Guex, J., Bartolini, A., Morettini, E., De Wever, P., 2003. A new scenario for the Domerian-Toarcian transition. Bulletin de la Société Géologique de France 174, 351-356.

Mort, H.P., Adatte, T., Föllmi, K.B., Keller, G., Steinmann, P., Matera, V., Berner, Z., Stüben, D., 2007. Phosphorus and the roles of productivity and nutrient recycling during oceanic anoxic event 2 . Geology $35,483-486$

Pierre, A., 2006. Un exemple de référence pour les systèmes de rampes oolitiques. Un affleurement continu de $37 \mathrm{~km}$ de long (falaises jurassiques d'Amellago, Haut Atlas, Maroc). Ph.D. thesis, Université de Bourgogne, Dijon, France. pp. 242.

Reboulet, S., Mattioli, E., Pittet, B., Baudin, F., Olivero, D., Proux, O., 2003. Ammonoid and nannoplankton abundance in Valanginian (early Cretaceous) limestone-marl successions from the southeast France Basin: carbonate dilution or productivity? Palaeogeography, Palaeoclimatology, Palaeoecology 201, 113-139.

Röhl, H.-J., Schmid-Röhl, A., Oschmann, W., Frimmel, A., Schwark, L., 2001. The Posidonia Shale (Lower Toarcian) of SW-Germany: an oxygen-depleted ecosystem controlled by sea level and palaeoclimate. Palaeogeography, Palaeoclimatology, Palaeoecology 165, 27-52.

Rosales, I., Quesada, S., Robles, S., 2004. Paleotemperature variations of Early Jurassic seawater recorded in geochemical trends of belemnites from the BasqueCantabrian Basin, northern Spain. Palaeogeography, Palaeoclimatology, Palaeoecology 203, 253-275.

Sabatino, N., Neri, R., Bellanca, A., Jenkyns, H.C., Baudin, F., Parisi, G., Masetti, D., 2009 Carbon-isotope records of the Early Jurassic (Toarcian) oceanic anoxic event from the Valdorbia (Umbria-Marche Apennines) and Monte Mangart (Julian Alps) sections: palaeoceanographic and stratigraphic implications. Sedimentology 56 1307-1328.

Sælen, G., Doyle, P., Talbot, M.R., 1996. Stable-isotope analyses of belemnite rostra from the Whitby Mudstone Fm., England: Surface water conditions during deposition of a marine black shale. Palaios 11, 97-117.

Schlager, W., 1981. The paradox of drowned reefs and carbonates platforms. Geological Society of America Bulletin 92, 197-211.

Schmid-Röhl, A., Röhl, H.-J., Oschmann, W., Frimmel, A., Schwark, L., 2002. Palaeoenvironmental reconstruction of Lower Toarcian epicontinental black shales (Posidonia Shale, SW Germany): global versus regional control. Geobios 35, 13-20.

Schouten, S., van Kaam-Peters, H.M.E., Rijpstra, W.I.C., Schoell, M., Sinninghe Damste, J.S., 2000. Effect of an oceanic anoxic event on the stable carbon isotopic composition of Early Toarcian carbon. American Journal of Science 300, 1-22.

Souhel, A., El Hariri, K., Chafiki, D., Canerot, J., 1998. Stratigraphie sequentielle et evolution geodynamique du Lias (Sinemurien terminal-Toarcien moyen) de l'Atlas de Beni-Mellal (Haut Atlas central, Maroc). Bulletin de la Société Géologique de France 169, 527-536.

Souhel, A., Canerot, J., El Bchari, F., Chafiki, D., Gharib, A., El Hariri, K., Bouchouata, A., 2000. The Liassic carbonate platform on the western part of the Central High Atlas (Morocco): stratigraphic and palaeogeographic patterns. In: Crasquin-Soleau, S. Barrier, E. (Eds.), Peri-Tethys Memoir 5: new data on Peri-Tethyan sedimentary basins: Memoire du Museum National d'Histoire Naturelle, Paris, pp. 39-56.

Studer, M., Du Dresnay, R., 1980. Déformations sédimentaires en compression pendant le Lias supérieur et le Dogger, au Tizi n'Irhil (Haut Atlas central de Midelt, Maroc). Bulletin de la Société Géologique de France 22, 391-397.

Suan, G., Mattioli, E., Pittet, B., Mailliot, S., Lécuyer, C., 2008a. Evidence for major environmental perturbation prior to and during the Toarcian (Early Jurassic) oceanic anoxic event from the Lusitanian Basin, Portugal. Paleoceanography 23, PA1202.

Suan, G., Pittet, B., Bour, I., Mattioli, E., Duarte, L.V., Mailliot, S., 2008b. Duration of the Early Toarcian carbon isotope excursion deduced from spectral analysis: consequence for its possible cause. Earth and Planetary Science Letters 267, 666-679.

Suan, G., Mattioli, E., Pittet, B., Lécuyer, C., Suchéras-Marx, B., Duarte, L.V., Philippe, M., Reggiani, L., Martineau, F., 2010. Secular environmental precursors to Early Toarcian (Jurassic) extreme climate changes. Earth and Planetary Science Letters $290,448-458$

Svensen, H., Planke, S., Chevallier, L., Malthe-Sorenssen, A., Corfu, F., Jamtveit, B., 2007. Hydrothermal venting of greenhouse gases triggering Early Jurassic global warming. Earth and Planetary Science Letters 256, 554-566.

Swart, P.K., Eberli, G.P., 2005. The nature of the $\delta^{13} \mathrm{C}$ of periplatform sediments: Implications for stratigraphy and the global carbon cycle. Sedimentary Geology $175,115-129$

Tremolada, F., van de Schootbrugge, B., Erba, E., 2005. Early Jurassic schizosphaerellid crisis in Cantabria, Spain: implications for calcification rates and phytoplankton evolutionacross the Toarcian oceanic anoxic event. Paleoceanography 20, PA2011.

Tyrrell, T., 1999. The relative influences of nitrogen and phosphorus on oceanic primary production. Nature 400, 525-531.

van Breugel, Y., Baas, M., Schouten, S., Mattioli, E., Damste, J.S.S., 2006. Isorenieratane record in black shales from the Paris Basin, France: constraints on recycling of respired $\mathrm{CO}_{2}$ as a mechanism for negative carbon isotope shifts during the Toarcian oceanic anoxic event. Paleoceanography 21, PA4220.

van de Schootbrugge, B., Kuhn, O., Adatte, T., Steinmann, P., Föllmi, K.B., 2003. Decoupling of $\mathrm{P}$ - and $\mathrm{C}_{\mathrm{org}}$-burial following Early Cretaceous (Valanginian- 
Hauterivian) platform drowning along the NW Tethyan margin. Palaeogeography, Palaeoclimatology, Palaeoecology 199, 315-331.

van de Schootbrugge, B., McArthur, J.M., Bailey, T.R., Rosenthal, Y., Wright, J.D., Miller, K.G. 2005. Toarcian oceanic anoxic event: an assessment of global causes using belemnite $C$ isotope records. Paleoceanography 20 PA3008, 1-10.

Vöros, A., 2002. Victims of the Early Toarcian anoxic event: the radiation and extinction of Jurassic Koninckinidae (Brachiopoda). Lethaia 35, 345-357.

Waltham, D.A., Gröcke, D.R., 2006. Non-uniqueness and interpretation of the seawate ${ }^{87} \mathrm{Sr} /{ }^{86} \mathrm{Sr}$ curve. Geochimica et Cosmochimica Acta 70, 384-394

Warme, J.E., 1988. Evolution of the Jurassic High Atlas rift, Morocco: transtension, structura and eustatic controls on carbonate facies, tectonic inversion. AAPG Field Seminar, 9: Exploration Geoscience Institute, Colorado, School of Mines, Golden, p. 332.

Weissert, H., 1989. C-isotope stratigraphy, a monitor of paleoenvironmental change: a case study from the Early Cretaceous. Surveys in Geophysics 10,1-61.

Weissert, H., Lini, A., Föllmi, K.B., Kuhn, O., 1998. Correlation of Early Cretaceous carbon isotope stratigraphy and platform drowning events: a possible link? Palaeogeography, Palaeoclimatology, Palaeoecology 137, 189-203.
Wignall, P.B., Bond, D.P.G., 2008. The end-Triassic and Early Jurassic mass extinction records in the British Isles. Proceedings of the Geologists' Association 119, 73-84.

Wignall, P.B., Newton, R.J., Little, C.T.S., 2005. The timing of paleoenvironmental change and cause-and-effect relationships during the early Jurassic mass extinction in Europe. American Journal of Science 305, 1014-1032.

Wilmsen, M., 2007. Integrated stratigraphy of the upper Lower-lower Middle Cenomanian of northern Germany and southern England. Acta Geologica Polonica 57, 263-279.

Wilmsen, M., Neuweiler, F., 2008. Biosedimentology of the Early Jurassic postextinction carbonate depositional system, central High Atlas rift basin, Morocco. Sedimentology 55, 773-807.

Woodfine, R.G., Jenkyns, H.C., Sarti, M., Baroncini, F., Violante, C., 2008. The response of two Tethyan carbonate platforms to the early Toarcian (Jurassic) oceanic anoxic event: environmental change and differential subsidence. Sedimentology 55, 1011-1028. 